\title{
Atmospheric Chemistry of Allylic Radicals from Isoprene: A Successive Cyclization-driven Autoxidation Mechanism
}

Fangfang Ma ${ }^{\dagger+l}$, Xirui Guo ${ }^{\dagger \mid l}$, Deming $\mathrm{Xia}^{\dagger}$, Hong-Bin Xie ${ }^{\dagger *}$, Yonghong Wang§, Jonas Elm ${ }^{\triangleleft}$, Jingwen Chen ${ }^{\dagger}$, Junfeng Niu ${ }^{\circ}$

†Key Laboratory of Industrial Ecology and Environmental Engineering (Ministry of Education), Dalian University of Technology, Dalian 116024, China

${ }^{\ddagger}$ Department of Atmospheric Sciences, Texas A\&M University, College Station, TX 77843, United States

§Institute for Atmospheric and Earth System Research, Faculty of Science, University of Helsinki, Helsinki 00014, Finland

${ }^{\Delta}$ Department of Chemistry and iClimate, Aarhus University, Langelandsgade 140, DK-8000 Aarhus C, Denmark

${ }^{\circ}$ Research Center for Eco-environmental Engineering, Dongguan University of Technology, Dongguan 523808, China

\section{Corresponding Author}

*Phone/fax: +86-411-84707251; e-mail:hbxie@dlut.edu.cn

Totally, 44 pages, 6 figures and 9 tables 


\section{Table of Contents}

A. Atmospheric lifetime $(\tau)$ of isoprene......................................................... S3

B. Contribution of $\mathrm{H}$-abstraction pathway to the removal of isoprene.................... S4

C. Details of AIMD for Producing Possible Reaction Pathways ............................ S5

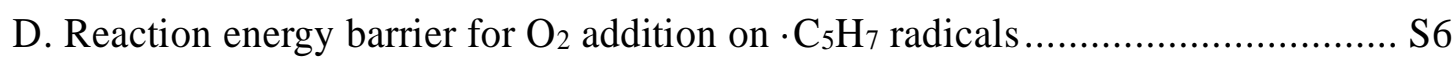

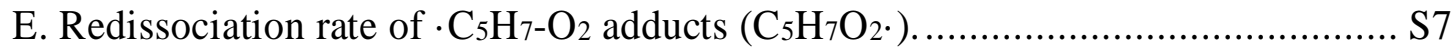

F. Determination of the crucial reaction steps for multi-conformer and F12a calculation S9

G. Computational details of the conformation sampling....................................S11

H. Multi-conformer unimolecular reaction rate constants.................................S15

I. ILT effect on the Time-dependence of fractional yields in the $\cdot \mathrm{C}_{5} \mathrm{H}_{7} / \mathrm{IM}_{1-7} / \mathrm{IM}_{2-6}+\mathrm{O}_{2}$ reactions

J. Schematic ZPE-corrected potential surface of self-isomerization/dissociation reaction for $\mathrm{IM}_{1-7}$

K. Schematic ZPE-corrected potential energy surfaces for $\mathrm{IM}_{1-7}+\mathrm{O}_{2}$ reaction and selfisomerization/dissociation reaction of $\mathrm{IM}_{2-6}$

L. Time-dependence of fractional yields in the $\mathrm{IM}_{1-7}+\mathrm{O}_{2}$ reactions......................S20

M. Schematic ZPE-corrected potential energy surfaces for $\mathrm{IM}_{2-6}+\mathrm{O}_{2}$ reaction ......S21

$\mathrm{N}$. Optimized geometries for the intermediates and transition states involved in the main atmospheric oxidation pathways of $\cdot \mathrm{C}_{5} \mathrm{H}_{7}$

O. $\mathrm{T}_{1}$ diagnostics values for the selected intermediates and transition states ..... S22

P. Lennard-Jones parameters used in the MESMER simulations S23

Q. Cartesian coordinates of the transition states for all reactions .523

I. Reference S42 
A. Atmospheric lifetime $(\tau)$ of isoprene. The atmospheric lifetime $(\tau)$ of isoprene caused by the reactions with hydroxy radicals $(\cdot \mathrm{OH})$, ozone $\left(\mathrm{O}_{3}\right)$ and chlorine radicals $(\cdot \mathrm{Cl})$ at daytime ( $\left.\tau_{\text {daytime}}\right)$ and $\mathrm{O}_{3}$ and nitrate radicals $\left(\mathrm{NO}_{3}\right)$ at night $\left(\tau_{\text {night }}\right)$ can be estimated by the following equations,

$$
\begin{array}{r}
\tau_{\text {daytime }}=1 /\left(\left[k \mathrm{OH}[\cdot \mathrm{OH}]+k_{\mathrm{O} 3}\left[\mathrm{O}_{3}\right]+k_{\mathrm{Cl}}[\cdot \mathrm{Cl}]\right)\right. \\
\tau_{\text {night }}=1 /\left(\left[\mathrm{ko}_{3}\left[\mathrm{O}_{3}\right]+k_{\mathrm{NO} 3}\left[\mathrm{NO}_{3}\right]\right)\right.
\end{array}
$$

where $k_{\mathrm{OH}}, k_{\mathrm{O}}, \mathrm{k}_{\mathrm{Cl}}$ and $k_{\mathrm{NO}}$ are reaction rate constants of isoprene with $\cdot \mathrm{OH}, \mathrm{O}_{3}, \cdot \mathrm{Cl}$ and $\mathrm{NO}_{3}$, respectively; $[\cdot \mathrm{OH}],\left[\mathrm{O}_{3}\right],[\cdot \mathrm{Cl}]$ and $\left[\mathrm{NO}_{3}\right]$ are the concentration of $\cdot \mathrm{OH}, \mathrm{O}_{3}$, $\cdot \mathrm{Cl}$ and $\mathrm{NO}_{3}$, respectively. The experimental values $\mathrm{kOH}_{\mathrm{OH}}=1.0 \times 10^{-10}, k_{\mathrm{O} 3}=1.3 \times 10^{-17}$, $k_{\mathrm{Cl}}=4.1 \times 10^{-10}$ and $k_{\mathrm{NO} 3}=6.5 \times 10^{-13} \mathrm{~cm}^{3}$ molecule $\mathrm{e}^{-1} \mathrm{~s}^{-1}$, and $[\cdot \mathrm{OH}]=2 \times 10^{6}$ molecule $\mathrm{cm}^{-3},[\cdot \mathrm{Cl}]=1-10 \%[\cdot \mathrm{OH}],\left[\mathrm{O}_{3}\right]=7 \times 10^{11}$ molecule $\mathrm{cm}^{-3}$ and $\left[\mathrm{NO}_{3}\right]=2.5 \times 10^{8}$ molecule $\mathrm{cm}^{-3}$ were employed in the calculation. ${ }^{1,2}$ The $\tau$ daytime and $\tau_{\text {night }}$ values are calculated to be 1.0-1.3 $\mathrm{h}$ and $1.6 \mathrm{~h}$, respectively. 
B. Contribution of $\mathbf{H}$-abstraction pathway to the removal of isoprene. As

mentioned in the section $\mathbf{A}$, reactions with $\cdot \mathrm{OH}, \cdot \mathrm{Cl}$ and $\mathrm{O}_{3}$ are the main transformation pathways of isoprene at daytime. Among the isoprene reactions, reactions with $\cdot \mathrm{Cl}$ and ·OH can proceed via an $\mathrm{H}$-abstraction pathway. The $\mathrm{H}$-abstraction pathway contributes $12.6 \%-17.4 \%$ (Table S1) and $\leq 1 \%$ to the removal of isoprene in $\cdot \mathrm{Cl}$ and $\cdot \mathrm{OH}$ initiated isoprene reaction, respectively. Since the H-abstraction pathway plays a minor role in the $\cdot \mathrm{OH}$-initiated reaction of isoprene, only $\cdot \mathrm{Cl}$-initiated reaction was considered in the assessment of the contribution of $\mathrm{H}$-abstraction pathway to the removal of isoprene. The contribution of H-abstraction pathway $\left(\Gamma_{\mathrm{H}}\right)$ can be calculated by

$$
\Gamma_{\mathrm{H}}=\left(\Gamma_{\mathrm{H}, \mathrm{Cl}} \times k_{\mathrm{Cl}}[\cdot \mathrm{Cl}]\right) /\left(\left[k_{\mathrm{OH}}[\cdot \mathrm{OH}]+k_{3}\left[\mathrm{O}_{3}\right]+k_{\mathrm{Cl}}[\cdot \mathrm{Cl}]\right)\right)
$$

Where $\Gamma_{\mathrm{H}, \mathrm{Cl}}$ is the contribution ratio $(12.6 \%-17.4 \%)$ of $\mathrm{H}$-abstraction pathway to the transformation of isoprene in the Cl-initiated reaction of isoprene. The employed $\mathrm{koH}$, $k_{\mathrm{Cl}}, k_{\mathrm{O}},[\cdot \mathrm{OH}],[\cdot \mathrm{Cl}]$, and $\left[\mathrm{O}_{3}\right]$ values are the same as those in $\tau_{\text {daytime calculation of }}$ isoprene (see section A), the contribution of $\mathrm{H}$-abstraction pathway to the removal of isoprene is calculated to be $3.6-4.9 \%$.

Table S1. Experimental and computational values of contribution ratios of $\mathrm{H}$ abstraction pathway $\left(\Gamma_{\mathrm{H}, \mathrm{Cl}}\right)$ to the removal of isoprene in the $\cdot \mathrm{Cl}+$ isoprene reaction.

\begin{tabular}{cc}
\hline$\Gamma_{\mathrm{H}, \mathrm{Cl}}$ & References \\
\hline$(13.1 \pm 5.8) \%$ & Ragains and Finlayson-Pitts $^{3}$ \\
$(15.4 \pm 1.8) \%$ & ${\text { Fantechi et } \mathrm{al}^{4}}$ \\
$(16.9 \pm 2.0) \%$ & ${\text { Bedjanian et } \mathrm{al}^{5}}{ }^{5} \%$ \\
$(17.4 \pm 0.4) \%$ & Suh and Zhang \\
$(12.6 \pm 0.3) \%$ & Xing et al ${ }^{7}$ \\
$17.4 \%$ & Guo et al $^{8}$ \\
\hline \hline
\end{tabular}


C. Details of AIMD for Producing Possible Reaction Pathways. In most reaction mechanism studies, the possible reaction pathways are proposed based on chemical intuition and experience. However, this could possibly lead to the important reaction pathways being overlooked, especially for reactions of complex compounds. To decrease such possibility, Ab Initio Molecular Dynamics (AIMD) simulations were complementally used as an alternative method to generate possible, if not important, reaction pathways. AIMD simulations were performed on the key complex intermediates involved in the target reactions. The BLYP functional ${ }^{9}$ along with the def2-SVP basis set within the RI approximation ${ }^{10}$ was used to conduct the AIMD simulations. The temperature was set to $500-1000 \mathrm{~K}$ to increase the possibility that the chemical reaction occurs during a short simulation time. A time step of 2 fs was used. The total length of each AIMD simulation was 10 ps. All the AIMD simulations were performed with Turbomole software. ${ }^{10}$ Cartesian coordinates for recording trajectories of the intermediates can be obtained from emailing to us. 
D. Reaction energy barrier for $\mathrm{O}_{2}$ addition on $\cdot \mathrm{C}_{5} \mathrm{H}_{7}$ radicals. Previous study found that the reactions of allyl radicals and $\cdot \mathrm{OH}$-isoprene adducts with $\mathrm{O}_{2}$ need overcome about $1 \mathrm{kcal} \mathrm{mol}^{-1}$ reaction energy barrier at B3LYP and MPW1B95 level of theory. ${ }^{11,12}$ We noted that the lowest reaction energy barrier for the reaction of $\cdot \mathrm{C}_{5} \mathrm{H}_{7}$ with $\mathrm{O}_{2}$ is 1.2 kcal mol-1 (Table S2) at M06-2X level of theory, the geometry optimization method used in this study. Such value is higher than that $\left(-1.3 \mathrm{kcal} \mathrm{mol}^{-1}\right)$ obtained at the CB3QB3 level of theory. To further probe the energy barrier height, ROHF-ROCCSD(T)-

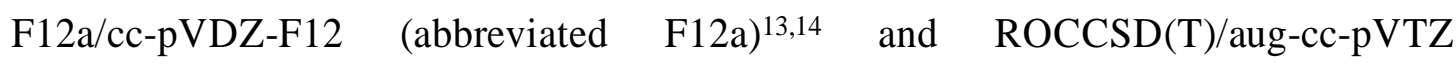
(abbreviated ROCCSD $(\mathrm{T}))^{15}$ methods were employed to perform single point energy calculation for the species involved in the $\mathrm{O}_{2}$ addition on the $\cdot \mathrm{C}_{5} \mathrm{H}_{7}$. As shown in Table S2, the values of the reaction energy barrier predicted by F12a and ROCCSD(T) are still negative. Therefore, the reaction of $\cdot \mathrm{C}_{5} \mathrm{H}_{7}$ with $\mathrm{O}_{2}$ should be barrierless based on the results from these high-level computational methods including CB3-QB3, F12a and ROCCSD(T). In addition, it was found that the predicted reaction energy barriers change with the selected computational methods. Even F12a and ROCCSD(T) methods can produce $2 \mathrm{kcal} \mathrm{mol}^{-1}$ difference in the predicted reaction energy barriers. It deserves mentioning that the change in the reaction rate constants in the entrance reaction pathway has little effect on the fractional yields in the $\cdot \mathrm{C}_{5} \mathrm{H}_{7}+\mathrm{O}_{2}$ reactions as discussed in the section $\mathbf{I}$. Therefore, the change in the reaction energy barriers due to the selected computational methods should have little effect on the pillar conclusion under study. More accurate methods such as complete active space self-consistent field (CASSCF) $)^{15}$ method are suggested to accurately predict the reaction energy barrier of allyl radicals with $\mathrm{O}_{2}$ in the future. 
Table S2. Calculated energy barriers $\left(\mathrm{kcal} \mathrm{mol}^{-1}\right)$ for the reaction of $\cdot \mathrm{C}_{5} \mathrm{H}_{7}$ with $\mathrm{O}_{2}$ at various computational methods.

\begin{tabular}{lcccc}
\hline Reactions & $\begin{array}{c}\text { M06-2X/ } \\
\text { 6-31+G(3df,2p) }\end{array}$ & CBS-QB3 & ROCCSD(T) & F12a \\
\hline $\mathrm{R}_{1} \rightarrow \mathrm{IM}_{1-1 \mathrm{a}}$ & 4.1 & 1.6 & 0.8 & -1.1 \\
$\mathrm{R}_{1} \rightarrow \mathrm{IM}_{1-1 \mathrm{~b}}$ & 1.2 & -1.3 & -3.4 & -5.4 \\
\hline \hline
\end{tabular}

E. Redissociation rate of $\cdot \mathrm{C}_{5} \mathrm{H}_{7}-\mathrm{O}_{2}$ adducts $\left(\mathrm{C}_{5} \mathrm{H}_{7} \mathrm{O}_{2}{ }^{\bullet}\right)$. Since the addition reaction of $\cdot \mathrm{C}_{5} \mathrm{H}_{7}$ and $\mathrm{O}_{2}$ is significantly less exothermic $\left(\sim 20 \mathrm{kcal} \mathrm{mol}^{-1}\right)$ than that of regular alkyl radicals and $\mathrm{O}_{2}\left(\sim 30 \mathrm{kcal} \mathrm{mol}^{-1}\right),{ }^{11,16-18}$ the formed $\cdot \mathrm{C}_{5} \mathrm{H}_{7}-\mathrm{O}_{2}$ adducts will have an opportunity to redissociate back to $\cdot \mathrm{C}_{5} \mathrm{H}_{7}+\mathrm{O}_{2}$. Here, the redissociation rate $(k$-o2) of $\cdot \mathrm{C}_{5} \mathrm{H}_{7}-\mathrm{O}_{2}$ adducts was calculated to evaluate the competition between the redissociation and further reactions of $\cdot \mathrm{C}_{5} \mathrm{H}_{7}-\mathrm{O}_{2}$ adducts. $k$-02 was calculated via $k-\mathrm{O}_{2}=$ $k_{+02} / K e q$, where $K e q$ is equilibrium constant between reactants $\left(\cdot \mathrm{C}_{5} \mathrm{H}_{7}\right.$ and $\left.\mathrm{O}_{2}\right)$ and $\cdot \mathrm{C}_{5} \mathrm{H}_{7}-\mathrm{O}_{2}$ adducts and $k+\mathrm{O} 2$ is the reaction rate constant of the addition reaction of $\mathrm{O}_{2}$ and $\cdot \mathrm{C}_{5} \mathrm{H}_{7}$. $k+\mathrm{O} 2$ was assumed to be $1.0 \times 10^{-12} \mathrm{~cm}^{3}$ molecule $\mathrm{e}^{-1} \mathrm{~s}^{-1}$, an experimental value for the allylic radicals with $\mathrm{O}_{2}$ in previous study. ${ }^{19}$ The $K_{\text {eq }}$ was calculated based on the multi-conformer approximation:

$$
\begin{gathered}
K_{\mathrm{eq}}=\sum_{i}^{\text {all IM }_{\mathrm{II-1}}^{\text {conf. }}} w_{i} K_{e q i} \\
w_{i}=\frac{e^{-\Delta G_{i} / k_{\mathrm{B}} T}}{\sum_{i} e^{-\Delta G_{i} / k_{\mathrm{B}} T}}
\end{gathered}
$$

where $K_{\text {eqi }}$ represents the equilibrium constant of conformer IM $_{1-1-i} i$ and $w_{\mathrm{i}}$ is the relative Boltzmann population of the corresponding conformer IM1-1-i. $w_{\mathrm{i}}$ is calculated by eq. 5 , where $\Delta G_{i}$ is the relative free energy of conformer $\mathrm{IM}_{1-1-i}$ (the free energy of global minimum is set as a reference state) obtained from F12a//M062X/6-31+G(3df,2p) level of theory, $k_{\mathrm{B}}$ is Boltzmann's constant and $T$ is the absolute temperature ( $T=298 \mathrm{~K}$ ). 
The $K_{\text {eqi }}$ values were calculated based on the energetic information from F12a//M062X/6-31+G(3df,2p) level of theory within the Thermo module of the MultiWell-2014.1 package. ${ }^{20-22}$ All calculated Keqi and the corresponding $w_{\text {i values }}$ were presented in Table S3. Based on these data, the $K_{\text {eq }}$ was calculated to be $8.6 \times 10^{-}$ ${ }^{13} \mathrm{~cm}^{3}$ molecule $\mathrm{e}^{-1}$ at $298 \mathrm{~K}$. Accordingly, $k$-02 is calculated to be $1.2 \mathrm{~s}^{-1}$ at $298 \mathrm{~K}$, which is higher than those of the bimolecular reactions of $\cdot \mathrm{C}_{5} \mathrm{H}_{7}-\mathrm{O}_{2}$ adducts with $\mathrm{NO}\left(0.03 \mathrm{~s}^{-}\right.$ $\left.{ }^{1}\right)$ and $\mathrm{HO}_{2} \cdot\left(0.02 \mathrm{~s}^{-1}\right)$ under $100 \mathrm{ppt} \mathrm{NO}$ and $50 \mathrm{ppt} \mathrm{HO}_{2}$. conditions, and the fastest unimolecular isomerization $\left(0.08 \mathrm{~s}^{-1}\right)$ of $\cdot \mathrm{C}_{5} \mathrm{H}_{7}-\mathrm{O}_{2}$ adducts.

Table S3. Calculated equilibrium constant $\left(K_{\text {eqi }}\right)$ of conformer IM1-1-i and Boltzmann population $\left(w_{i}\right)$ of the conformer $\mathrm{IM}_{1-1-i}$ at the F12a//M06-2X/6-31+G(3df,2p) level of theory.

\begin{tabular}{|c|c|c|}
\hline Species & $W_{i}$ & $K_{\text {eqi }}\left(\mathrm{cm}^{3}\right.$ molecule $\left.^{-1}\right)$ \\
\hline $\mathrm{IM}_{1-1-1}$ & 0.1549 & $1.11 \times 10^{-12}$ \\
\hline $\mathrm{IM}_{1-1-2}$ & 0.1538 & $1.09 \times 10^{-12}$ \\
\hline $\mathrm{IM}_{1-1-3}$ & 0.1441 & $1.02 \times 10^{-12}$ \\
\hline $\mathrm{IM}_{1-1-4}$ & 0.1436 & $1.02 \times 10^{-12}$ \\
\hline $\mathrm{IM}_{1-1-5}$ & 0.1032 & $7.26 \times 10^{-13}$ \\
\hline $\mathrm{IM}_{1-1-6}$ & 0.1002 & $7.12 \times 10^{-13}$ \\
\hline $\mathrm{IM}_{1-1-7}$ & 0.0999 & $7.12 \times 10^{-13}$ \\
\hline $\mathrm{IM}_{1-1-8}$ & 0.0143 & $9.99 \times 10^{-14}$ \\
\hline $\mathrm{IM}_{1-1-9}$ & 0.0143 & $9.95 \times 10^{-14}$ \\
\hline $\mathrm{IM}_{1-1-10}$ & 0.0141 & $9.72 \times 10^{-14}$ \\
\hline $\mathrm{IM}_{1-1-11}$ & 0.0123 & $8.58 \times 10^{-14}$ \\
\hline $\mathrm{IM}_{1-1-12}$ & 0.0072 & $4.99 \times 10^{-14}$ \\
\hline $\mathrm{IM}_{1-1-13}$ & 0.0072 & $4.98 \times 10^{-14}$ \\
\hline $\mathrm{IM}_{1-1-14}$ & 0.0055 & $3.80 \times 10^{-14}$ \\
\hline $\mathrm{IM}_{1-1-15}$ & 0.0055 & $3.74 \times 10^{-14}$ \\
\hline $\mathrm{IM}_{1-1-16}$ & 0.0053 & $3.64 \times 10^{-14}$ \\
\hline $\mathrm{IM}_{1-1-17}$ & 0.0053 & $3.63 \times 10^{-14}$ \\
\hline $\mathrm{IM}_{1-1-18}$ & 0.0047 & $3.19 \times 10^{-14}$ \\
\hline $\mathrm{IM}_{1-1-19}$ & 0.0046 & $3.20 \times 10^{-14}$ \\
\hline
\end{tabular}




\section{F. Determination of the crucial reaction steps for multi-conformer and F12a}

calculation. All the entrance reaction steps of allylic radicals and alkyl radicals with $\mathrm{O}_{2}$ for the target reactions were not considered as the crucial reaction steps since there are no competitive reactions for them. In addition, the fixed reaction rate constants for the bimolecular reactions of formed peroxy radicals with $\mathrm{NO} / \mathrm{HO}_{2} \cdot\left(k_{\mathrm{NO}}=11.5 \times 10^{-12}\right.$ $\mathrm{cm}^{3}$ molecule $\mathrm{e}^{-1} \mathrm{~s}^{-1}, \mathrm{kHO} 2=1.7 \times 10^{-11} \mathrm{~cm}^{3}$ molecule $\mathrm{e}^{-1} \mathrm{~s}^{-1}$ ) and C-centered radicals with $\mathrm{O}_{2}\left(k \mathrm{o} 2,1.0 \times 10^{-12} \mathrm{~cm}^{3}\right.$ molecule $\mathrm{e}^{-1} \mathrm{~s}^{-1}$ (allylic radicals) or $6.0 \times 10^{-12} \mathrm{~cm}^{3}$ molecule $\mathrm{s}^{-1}$

${ }^{1}$ (alkyl radicals)) were used in evaluating their competition with the corresponding

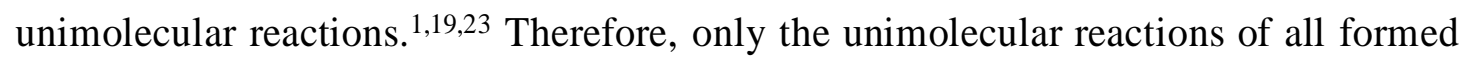
peroxy radicals and C-centered radicals are potential crucial reaction steps. Based on the ZPE-corrected potential energy surface from the single-conformer approximation and CBS-QB3//M06-2X/6-31+G(3df,2p) level of theory, $\mathrm{IM}_{1-1} \rightarrow \mathrm{IM}_{1-7} \rightarrow \mathrm{IM}_{1-13}$ is determined to be the most favorable unimolecular reaction pathways starting from $\cdot \mathrm{C}_{5} \mathrm{H}_{7}+\mathrm{O}_{2}$. The high-pressure limit reaction rate constant for $\mathrm{IM}_{1-1} \rightarrow \mathrm{IM}_{1-7}$ is calculated to be $10.5 \mathrm{~s}^{-1}$, about two orders of magnitude higher than the reaction rate constants of IM1-1 reaction with $\mathrm{NO} / \mathrm{HO}_{2} \cdot\left(0.03 / 0.02 \mathrm{~s}^{-1}\right)$ based on $100 \mathrm{ppt} \mathrm{NO}$ and 50 ppt $\mathrm{HO}_{2}$. The two orders of magnitude difference in reaction rate constants could still be a possible computational error range caused by CBS-QB3//M06-2X/6-31+G(3df,2p) and single-conformer approximation calculation. Therefore, IM1-1 $\rightarrow$ IM1-7 is selected as one crucial step for the reaction of $\cdot_{5} \mathrm{H}_{7}$ with $\mathrm{O}_{2}$. To further consider the effect of possible computational error on the competition of unimolecular reaction of IM1-1, step $\mathrm{IM}_{1-1} \rightarrow \mathrm{IM}_{1-8}$, which reaction energy barrier is the closest to that of $\mathrm{IM}_{1-1} \rightarrow \mathrm{IM}_{1-7}$, is also selected as one crucial step for the reaction of $\cdot \mathrm{C}_{5} \mathrm{H}_{7}$ with $\mathrm{O}_{2}$. In addition, the highpressure limit reaction rate constant for $\operatorname{IM}_{1-7} \rightarrow \operatorname{IM}_{1-1}\left(2.5 \times 10^{4} \mathrm{~s}^{-1}\right)$ is much higher 
than that $\left(3.0 \times 10^{-9} \mathrm{~s}^{-1}\right)$ of $\mathrm{IM}_{1-7} \rightarrow \mathrm{IM}_{1-13}$. However, it could be comparable to the reaction rate constant $\left(3.0 \times 10^{7} \mathrm{~s}^{-1}\right)$ of $\mathrm{IM}_{1-7}$ with $\mathrm{O}_{2}$ (the concentration of $\mathrm{O}_{2}$ of $5.0 \times$ $10^{18}$ molecule $\mathrm{cm}^{-3}$ ) within the range of the possible computational error. Therefore, $\mathrm{IM}_{1-7} \rightarrow \mathrm{IM}_{1-1}$ is also selected as one crucial step for the reaction of $\cdot \mathrm{C}_{5} \mathrm{H}_{7}$ with $\mathrm{O}_{2}$. All in all, $\mathrm{IM}_{1-1} \leftrightarrow \mathrm{IM}_{1-7}$ and $\mathrm{IM}_{1-1} \rightarrow \mathrm{IM}_{1-8}$ are determined as the final crucial reaction steps for the reaction of $\cdot \mathrm{C}_{5} \mathrm{H}_{7}$ with $\mathrm{O}_{2}$. Based on the same principle, the steps $\mathrm{IM}_{2-1} \rightarrow$ $\mathrm{IM}_{2-5}, \mathrm{IM}_{2-1} \rightarrow \mathrm{IM}_{2-6}$ and $\mathrm{IM}_{2-1} \rightarrow \mathrm{IM}_{2-7}$, and $\mathrm{IM}_{3-1} \rightarrow \mathrm{IM}_{3-3}$ and $\mathrm{IM}_{3-1} \rightarrow \mathrm{IM}_{3-3}$ are selected as crucial ones for the reactions of $\mathrm{IM}_{1-7}+\mathrm{O}_{2}$ and $\mathrm{IM}_{2-6}+\mathrm{O}_{2}$, respectively. The applied reaction rate constants for these selected steps are presented in Table S4.

Table S4. Calculated high-pressure limit reaction rate constants $(k)$ for the favorable reaction pathways in the reaction system of $\cdot_{5} \mathrm{C}_{7}$ with $\mathrm{O}_{2}$ based on the energetic data from single-conformer approximation and CBS-QB3//M06-2X/6-31+G(3df,2p) level of theory.

\begin{tabular}{cc}
\hline \hline Reactions & $k\left(\mathrm{~s}^{-1}\right)$ \\
\hline $\mathrm{IM}_{1-1} \rightarrow \mathrm{IM}_{1-7}$ & 10.5 \\
$\mathrm{IM}_{1-1} \rightarrow \mathrm{IM}_{1-8}$ & 0.04 \\
$\mathrm{IM}_{1-7} \rightarrow \mathrm{IM}_{1-13}$ & $3.0 \times 10^{-9}$ \\
$\mathrm{IM}_{1-7} \rightarrow \mathrm{IM}_{1-1}$ & $2.5 \times 10^{4}$ \\
$\mathrm{IM}_{2-1} \rightarrow \mathrm{IM}_{2-5}$ & 46.4 \\
$\mathrm{IM}_{2-1} \rightarrow \mathrm{IM}_{2-6}$ & 88.1 \\
$\mathrm{IM}_{2-1} \rightarrow \mathrm{IM}_{2-7}$ & 1.8 \\
$\mathrm{IM}_{2-6} \rightarrow \mathrm{IM}_{2-13}$ & 0.02 \\
$\mathrm{IM}_{2-13} \rightarrow \mathrm{IM}_{2-15}$ & 0.1 \\
$\mathrm{IM}_{3-1} \rightarrow \mathrm{IM}_{3-3}$ & 0.05 \\
$\mathrm{IM}_{3-1} \rightarrow \mathrm{IM}_{3-5}$ & 1.5 \\
$\mathrm{IM}_{3-5} \rightarrow \mathrm{IM}_{3-1}$ & $4.0 \times 10^{7}$ \\
$\mathrm{IM}_{3-5} \rightarrow \mathrm{IM}_{3-7}$ & $1.3 \times 10^{13}$ \\
$\mathrm{IM}_{3-7} \rightarrow \mathrm{IM}_{3-8}$ & $4.4 \times 10^{10}$ \\
$\mathrm{IM}_{3-8} \rightarrow \mathrm{IM}_{3-1}$ & $6.4 \times 10^{13}$ \\
\hline \hline
\end{tabular}


G. Computational details of the conformation sampling. To sample the various conformations of intermediates ( $\mathrm{IM}_{1-1}, \mathrm{IM}_{2-1}, \mathrm{IM}_{3-1}$ and $\left.\mathrm{IM}_{1-7}\right)$ and transition states (TS 1-7, $\mathrm{TS}_{1-8}, \mathrm{TS}_{2-5}, \mathrm{TS}_{2-6}, \mathrm{TS}_{2-7}, \mathrm{TS}_{3-3}$, and $\mathrm{TS}_{3-5}$ ) in the selected crucial reaction steps, Born-Oppenheimer Molecular Dynamics (BOMD) simulations were performed for the selected each species within the CP2K package ${ }^{24}$ based on the optimized geometries at the M06-2X/6-31+G(3df,2pd) level of theory. The spatial dimensions of the simulated cubic box are $15 \AA \times 15 \AA \times 15 \AA$. The BLYP functional with Grimme's dispersion correction D3 was employed (BLYP-D3) ${ }^{25}$. A double- $\zeta$ Gaussian-type basis $\operatorname{set}^{26}$ and the norm-conserving Goedecker-Teter-Hutter (GTH) pseudo-potentials ${ }^{27}$ were adopted to treat the valence and core electrons, respectively. An energy cutoff of 300 Rydberg and 40 Rydberg were imposed for the plane wave basis set and Gaussian basis set, respectively. The simulations were carried out in NVT ensemble with the temperature of $500 \mathrm{~K}$ being controlled by the Nose-Hoover chain coupling method. The reason for selecting the high temperature $(500 \mathrm{~K})$ is that enough conformers can be sampled in relative short simulation time. The similar high temperature simulation for the conformation sampling was performed in our previous studies. ${ }^{28-30}$ The integration step was set as $1.0 \mathrm{fs}^{31}$ and each BOMD simulation was run for about 15.0 ps. The BOMD simulations for transition states have been constrained by freezing key bond lengths, a similar scheme for transition state conformation sampling in the studies by Møller et al. ${ }^{16,32-34}$ The simulations for intermediates were free of constraints. Based on BOMD trajectories, various conformations (about 40) were selected as the starting points for geometry optimization at the M062X/6-31+G(3df,2p) level, followed by F12a single point energy calculation. Based on the calculated free energies of each conformer, Boltzmann populations $\left(w_{i}\right)$ for conformer $i$ is calculated by eq.5. The 
calculated relative free energy and the corresponding Boltzmann population of intermediates and TSs were presented in Table S5.

Table S5. Calculated relative free energy ( $\Delta G_{\mathrm{i}}$, the free energy of global minimum is set as a reference state for each species) and Boltzmann populations ( $\left.w_{i}\right)$ of the selected intermediates and transition states at the F12a//M06-2X/6-31+G(3df,2p) level of theory.

\begin{tabular}{|c|c|c|}
\hline Species & $\Delta G_{\mathrm{i}}\left(\mathrm{kcal} \mathrm{mol}^{-1}\right)$ & $w_{i}$ \\
\hline $\mathrm{IM}_{1-1-1}$ & 0.0000 & 0.1549 \\
\hline $\mathrm{IM}_{1-1-2}$ & 0.0043 & 0.1538 \\
\hline $\mathrm{IM}_{1-1-3}$ & 0.0434 & 0.1441 \\
\hline $\mathrm{IM}_{1-1-4}$ & 0.0455 & 0.1436 \\
\hline $\mathrm{IM}_{1-1-5}$ & 0.2431 & 0.1032 \\
\hline $\mathrm{IM}_{1-1-6}$ & 0.2607 & 0.1002 \\
\hline $\mathrm{IM}_{1-1-7}$ & 0.2626 & 0.0999 \\
\hline $\mathrm{IM}_{1-1-8}$ & 1.4250 & 0.0143 \\
\hline $\mathrm{IM}_{1-1-9}$ & 1.4283 & 0.0143 \\
\hline $\mathrm{IM}_{1-1-10}$ & 1.4346 & 0.0141 \\
\hline $\mathrm{IM}_{1-1-11}$ & 1.5149 & 0.0123 \\
\hline $\mathrm{IM}_{1-1-12}$ & 1.8370 & 0.0072 \\
\hline $\mathrm{IM}_{1-1-13}$ & 1.8380 & 0.0072 \\
\hline $\mathrm{IM}_{1-1-14}$ & 1.9989 & 0.0055 \\
\hline $\mathrm{IM}_{1-1-15}$ & 2.0028 & 0.0055 \\
\hline $\mathrm{IM}_{1-1-16}$ & 2.0208 & 0.0053 \\
\hline $\mathrm{IM}_{1-1-17}$ & 2.0220 & 0.0053 \\
\hline $\mathrm{IM}_{1-1-18}$ & 2.0983 & 0.0047 \\
\hline $\mathrm{IM}_{1-1-19}$ & 2.0992 & 0.0046 \\
\hline $\mathrm{IM}_{2-1-1}$ & 0.0000 & 0.5316 \\
\hline $\mathrm{IM}_{2-1-2}$ & 0.8363 & 0.1315 \\
\hline $\mathrm{IM}_{2-1-3}$ & 1.2755 & 0.0631 \\
\hline $\mathrm{IM}_{2-1-4}$ & 1.3464 & 0.0561 \\
\hline $\mathrm{IM}_{2-1-5}$ & 1.6743 & 0.0324 \\
\hline $\mathrm{IM}_{2-1-6}$ & 1.7567 & 0.0283 \\
\hline $\mathrm{IM}_{2-1-7}$ & 1.7841 & 0.0270 \\
\hline $\mathrm{IM}_{2-1-8}$ & 1.8197 & 0.0254 \\
\hline $\mathrm{IM}_{2-1-9}$ & 1.9993 & 0.0188 \\
\hline $\mathrm{IM}_{2-1-10}$ & 2.1190 & 0.0154 \\
\hline $\mathrm{IM}_{2-1-11}$ & 2.2728 & 0.0119 \\
\hline $\mathrm{IM}_{2-1-12}$ & 2.3082 & 0.0112 \\
\hline $\mathrm{IM}_{2-1-13}$ & 2.3569 & 0.0104 \\
\hline $\mathrm{IM}_{2-1-14}$ & 2.4494 & 0.0089 \\
\hline $\mathrm{IM}_{2-1-15}$ & 2.5342 & 0.0077 \\
\hline
\end{tabular}




\begin{tabular}{|c|c|c|}
\hline $\mathrm{IM}_{2-1-16}$ & 2.5784 & 0.0072 \\
\hline $\mathrm{IM}_{2-1-17}$ & 2.6731 & 0.0061 \\
\hline $\mathrm{IM}_{2-1-18}$ & 2.8112 & 0.0049 \\
\hline $\mathrm{IM}_{2-1-19}$ & 3.4293 & 0.0017 \\
\hline $\mathrm{IM}_{2-1-20}$ & 4.4305 & 0.0004 \\
\hline $\mathrm{IM}_{3-1-1}$ & 0.0000 & 0.1688 \\
\hline $\mathrm{IM}_{3-1-2}$ & 0.1503 & 0.1313 \\
\hline $\mathrm{IM}_{3-1-3}$ & 0.3045 & 0.1015 \\
\hline $\mathrm{IM}_{3-1-4}$ & 0.3648 & 0.0918 \\
\hline $\mathrm{IM}_{3-1-5}$ & 0.5942 & 0.0626 \\
\hline IM3-1-6 & 0.6137 & 0.0605 \\
\hline $\mathrm{IM}_{3-1-7}$ & 0.6207 & 0.0598 \\
\hline $\mathrm{IM}_{3-1-8}$ & 0.7043 & 0.0520 \\
\hline IM $3-1-9$ & 0.7208 & 0.0506 \\
\hline $\mathrm{IM}_{3-1-10}$ & 0.9927 & 0.0321 \\
\hline $\mathrm{IM}_{3-1-11}$ & 1.0085 & 0.0313 \\
\hline $\mathrm{IM}_{3-1-12}$ & 1.0345 & 0.0300 \\
\hline $\mathrm{IM}_{3-1-13}$ & 1.1995 & 0.0228 \\
\hline $\mathrm{IM}_{3-1-14}$ & 1.2350 & 0.0214 \\
\hline $\mathrm{IM}_{3-1-15}$ & 1.2604 & 0.0206 \\
\hline $\mathrm{IM}_{3-1-16}$ & 1.2878 & 0.0196 \\
\hline $\mathrm{IM}_{3-1-17}$ & 1.3942 & 0.0164 \\
\hline $\mathrm{IM}_{3-1-18}$ & 1.4937 & 0.0139 \\
\hline $\mathrm{IM}_{3-1-19}$ & 1.5415 & 0.0130 \\
\hline $\mathrm{IM}_{1-7-1}$ & 0.0000 & 0.2851 \\
\hline $\mathrm{IM}_{1-7-2}$ & 0.0003 & 0.2849 \\
\hline $\mathrm{IM}_{\text {1-7-3 }}$ & 0.7420 & 0.0825 \\
\hline $\mathrm{IM}_{1-7-4}$ & 0.7431 & 0.0824 \\
\hline $\mathrm{IM}_{1-7-5}$ & 0.7515 & 0.0812 \\
\hline $\mathrm{IM}_{\text {1-7-6 }}$ & 0.8704 & 0.0666 \\
\hline $\mathrm{IM}_{1-7-7}$ & 0.8709 & 0.0665 \\
\hline $\mathrm{IM}_{1-7-8}$ & 1.0337 & 0.0508 \\
\hline $\mathrm{TS}_{1-7-1}$ & 0.0000 & 0.4888 \\
\hline $\mathrm{TS}_{1-7-2}$ & 0.0021 & 0.4871 \\
\hline $\mathrm{TS}_{1-7-3}$ & 2.2174 & 0.0121 \\
\hline $\mathrm{TS}_{1-7-4}$ & 2.2118 & 0.0120 \\
\hline $\mathrm{TS}_{1-8-1} *$ & 0.0000 & 0.7384 \\
\hline $\mathrm{TS}_{1-8-2 *}$ & 0.6211 & 0.2616 \\
\hline $\mathrm{TS}_{2-5-1}$ & 0.0000 & 0.8139 \\
\hline $\mathrm{TS}_{2-5-2}$ & 0.8832 & 0.1861 \\
\hline $\mathrm{TS}_{2-6-1}$ & 0.0000 & 0.9801 \\
\hline $\mathrm{TS}_{2-6-2}$ & 2.4281 & 0.0170 \\
\hline $\mathrm{TS}_{2-6-3}$ & 3.7015 & 0.0020 \\
\hline $\mathrm{TS}_{2-6-4}$ & 4.1584 & 0.0009 \\
\hline
\end{tabular}




\begin{tabular}{|c|c|c|}
\hline $\mathrm{TS}_{2-7-1} *$ & 0.0000 & 0.9776 \\
\hline $\mathrm{TS}_{2-7-2 *}$ & 2.4974 & 0.0151 \\
\hline $\mathrm{TS}_{2-7-3} *$ & 3.2277 & 0.0045 \\
\hline $\mathrm{TS}_{2-7-4^{*}}$ & 3.4969 & 0.0028 \\
\hline $\mathrm{TS}_{3-3-1}$ & 0.0000 & 0.9756 \\
\hline TS $3-3-2$ & 2.4898 & 0.0152 \\
\hline TS $3-3-3$ & 3.0428 & 0.0061 \\
\hline $\mathrm{TS}_{3-3-4}$ & 3.4456 & 0.0031 \\
\hline $\mathrm{TS}_{3-5-1}$ & 0.0000 & 0.7518 \\
\hline $\mathrm{TS}_{3-5-2}$ & 0.7115 & 0.2291 \\
\hline $\mathrm{TS}_{3-5-3}$ & 2.2629 & 0.0172 \\
\hline $\mathrm{TS}_{3-5-4}$ & 3.5512 & 0.0019 \\
\hline
\end{tabular}

* Since part of calculation failed (convergence problems) at the F12a level although lots of attempts were performed, the ROCCSD(T)//M06-2X/6-31+G(3df,2p) level of theory was used instead. In addition, the ROCCSD(T)//M062X/6-31+G(3df,2p) level of theory can give a very similar reaction energy barrier as F12a for the test case, implying such alternative for F12a is acceptable. 
H. Multi-conformer unimolecular reaction rate constants. Multi-conformer transition state theory (MC-TST) ${ }^{35}$ was performed on the selected crucial reaction pathways (IM1-1 $\leftrightarrow$ IM1-7; IM1-1 $\rightarrow$ IM$_{1-8}$; IM2-1 $\rightarrow$ IM2-5; IM2-1 $\rightarrow$ IM$_{2-6} ;$ IM$_{2-1} \rightarrow$ IM$_{2-}$ 7; IM3-1 $\rightarrow$ IM3-3 and IM3-1 $\rightarrow$ IM3-5) based on the energetic data at the F12a//M062X/6-31+G(3df,2p) level of theory. As shown in Table S5, 8-20 conformers are found for the intermediates (IM1-1, IM 2-1, IM-1, and IM1-7), and 2-4 conformers for the transition states ( $\mathrm{TS}_{1-7}, \mathrm{TS}_{1-8}, \mathrm{TS}_{2-5}, \mathrm{TS}_{2-6}, \mathrm{TS}_{2-7}, \mathrm{TS} 3-3$ and $\mathrm{TS}_{3-5}$ ). The multi-conformer reaction rate constant $\left(k_{\text {MC-TST }}\right)$ was calculated by the weighted sum of single-conformer reaction rate constants (refer to as intrinsic reaction coordinate (IRC) TST) (kIRC-TST):

$$
k_{\mathrm{MC}-\mathrm{TST}}=\sum_{i}^{\text {all TS conf. }} w_{i} k_{\mathrm{IRC}-\mathrm{TST} i}
$$

where $k_{\text {IRC-TSTi }}$ represents the reaction rate constant of $\mathrm{TS}_{i}$ and $w_{\mathrm{i}}$ is the relative Boltzmann populations of the corresponding reactant conformer of $\mathrm{TS}_{i}$ (calculated by eq (5)). It deserves mentioning that this summation runs over all conformers of the transition states. Therefore, the sum of all wi used in each kMC-TST calculation is less or (much less) than 1 since the number of conformers of the transition states is less or (much less) than that of conformers of corresponding reactants. The $k_{\text {IRC-TSTi }}$ values were calculated using the canonical transition state theory (TST) within the Thermo module of the MultiWell-2014.1 package. ${ }^{20-22}$ The all calculated kIRC-TSTi and the corresponding $w_{\mathrm{i}}$ values for the selected pathways were presented in Table S6. Based on these data, the calculated multi-conformer $k_{\text {MC-TST }}$ for IM $_{1-1} \rightarrow$ IM1-7 $_{1}$ IM1-1 $_{1} \rightarrow$ IM1- $_{1-}$ 8; $\mathrm{IM}_{1-7} \rightarrow \mathrm{IM}_{1-1} ; \mathrm{IM}_{2-1} \rightarrow \mathrm{IM}_{2-5} ; \mathrm{IM}_{2-1} \rightarrow \mathrm{IM}_{2-6} ; \mathrm{IM}_{2-1} \rightarrow \mathrm{IM}_{2-7} ; \mathrm{IM}_{3-1} \rightarrow \mathrm{IM}_{3-3}$ and $\mathrm{IM}_{3-}$ $1 \rightarrow \mathrm{IM}_{3-5}$ are $0.08,5.2 \times 10^{-4}, 1.7 \times 10^{3}, 0.07,119,0.9,0.5$ and $0.7 \mathrm{~s}^{-1}$, respectively. 
Table S6. Calculated multi-conformer reaction rate constants (kMC-TST), corresponding single-conformer reaction rate constant $\left(k_{\mathrm{IRC}-\mathrm{TST} i}\right)$ of transition state $i\left(\mathrm{TS}_{i}\right)$ and relative Boltzmann populations $\left(w_{\mathrm{i}}\right)$ of the reactant conformer connected to $\mathrm{TS}_{i}$ based on the energetic data at the F12a//M06-2X/6-31+G(3df,2p) level of theory.

\begin{tabular}{|c|c|c|c|c|}
\hline Reaction steps & TSs & $k_{\text {IRC-TSTi }}\left(\mathrm{s}^{-1}\right)$ & $w_{\mathrm{i}}$ & kMC-TST $\left(\mathrm{s}^{-1}\right)$ \\
\hline \multirow{4}{*}{$\mathrm{IM}_{1-1} \rightarrow \mathrm{IM}_{1-7}$} & $\mathrm{TS}_{1-7-1}$ & 6.7 & 0.0055 & \multirow[t]{4}{*}{0.08} \\
\hline & $\mathrm{TS}_{1-7-2}$ & 6.7 & 0.0055 & \\
\hline & $\mathrm{TS}_{1-7-3}$ & 0.2 & 0.0046 & \\
\hline & $\mathrm{TS}_{1-7-4}$ & 0.2 & 0.0047 & \\
\hline \multirow{4}{*}{$\mathrm{IM}_{1-7} \rightarrow \mathrm{IM}_{1-1}$} & $\mathrm{TS}_{1-7-1}$ & $2.9 \times 10^{3}$ & 0.2849 & \multirow[t]{4}{*}{$1.7 \times 10^{3}$} \\
\hline & $\mathrm{TS}_{1-7-2}$ & $1.0 \times 10^{4}$ & 0.0824 & \\
\hline & $\mathrm{TS}_{1-7-3}$ & 68.7 & 0.2849 & \\
\hline & $\mathrm{TS}_{1-7-4}$ & 68.9 & 0.2861 & \\
\hline \multirow{2}{*}{$\mathrm{IM}_{1-1} \rightarrow \mathrm{IM}_{1-8}$} & $\mathrm{TS}_{1-8-1}$ & $2.5 \times 10^{-3 *}$ & 0.1549 & \multirow[t]{2}{*}{$5.2 \times 10^{-4}$} \\
\hline & $\mathrm{TS}_{1-8-2}$ & $8.7 \times 10^{-4 *}$ & 0.1549 & \\
\hline \multirow{2}{*}{$\mathrm{IM}_{2-1} \rightarrow \mathrm{IM}_{2-5}$} & $\mathrm{TS}_{2-5-1}$ & 30.8 & 0.0017 & \multirow[t]{2}{*}{0.07} \\
\hline & $\mathrm{TS}_{2-5-2}$ & 1.8 & 0.0077 & \\
\hline \multirow{4}{*}{$\mathrm{IM}_{2-1} \rightarrow \mathrm{IM}_{2-6}$} & $\mathrm{TS}_{2-6-1}$ & $4.1 \times 10^{3}$ & 0.0283 & \multirow[t]{4}{*}{119} \\
\hline & $\mathrm{TS}_{2-6-2}$ & $6.2 \times 10^{3}$ & 0.0004 & \\
\hline & $\mathrm{TS}_{2-6-3}$ & 14.6 & 0.0154 & \\
\hline & $\mathrm{TS}_{2-6-4}$ & 13.7 & 0.0077 & \\
\hline \multirow{4}{*}{$\mathrm{IM}_{2-1} \rightarrow \mathrm{IM}_{2-7}$} & $\mathrm{TS}_{2-7-1}$ & $31.9 *$ & 0.0283 & \multirow[t]{4}{*}{0.9} \\
\hline & $\mathrm{TS}_{2-7-2}$ & $3.0^{*}$ & 0.0004 & \\
\hline & $\mathrm{TS}_{2-7-3}$ & $0.5^{*}$ & 0.0077 & \\
\hline & $\mathrm{TS}_{2-7-4}$ & $0.2^{*}$ & 0.0154 & \\
\hline \multirow{4}{*}{$\mathrm{IM}_{3-1} \rightarrow \mathrm{IM}_{3-3}$} & TS $3-3-1$ & 19.5 & 0.0228 & \multirow[t]{4}{*}{0.5} \\
\hline & TS $3-3-2$ & 0.7 & 0.03 & \\
\hline & $\mathrm{TS}_{3-3-3}$ & 0.08 & 0.1015 & \\
\hline & $\mathrm{TS}_{3-3-4}$ & 0.1 & 0.0506 & \\
\hline \multirow{4}{*}{$\mathrm{IM}_{3-1} \rightarrow \mathrm{IM}_{3-5}$} & $\mathrm{TS}_{3-5-1}$ & 22.1 & 0.0214 & \multirow[t]{4}{*}{0.7} \\
\hline & $\mathrm{TS}_{3-5-2}$ & 4.6 & 0.0313 & \\
\hline & TS $3-5-3$ & 1.1 & 0.0321 & \\
\hline & $\mathrm{TS}_{3-5-4}$ & 0.1 & 0.0520 & \\
\hline
\end{tabular}

*The results are based on the energetic data from the ROCCSD(T)//M062X/6-31+G(3df,2p) level of theory. 
I. ILT effect on the Time-dependence of fractional yields in the $\cdot \mathrm{C}_{5} \mathrm{H}_{7} / \mathrm{IM}_{1-7} / \mathrm{IM}_{2-6}$

\section{$+\mathrm{O}_{2}$ reactions}
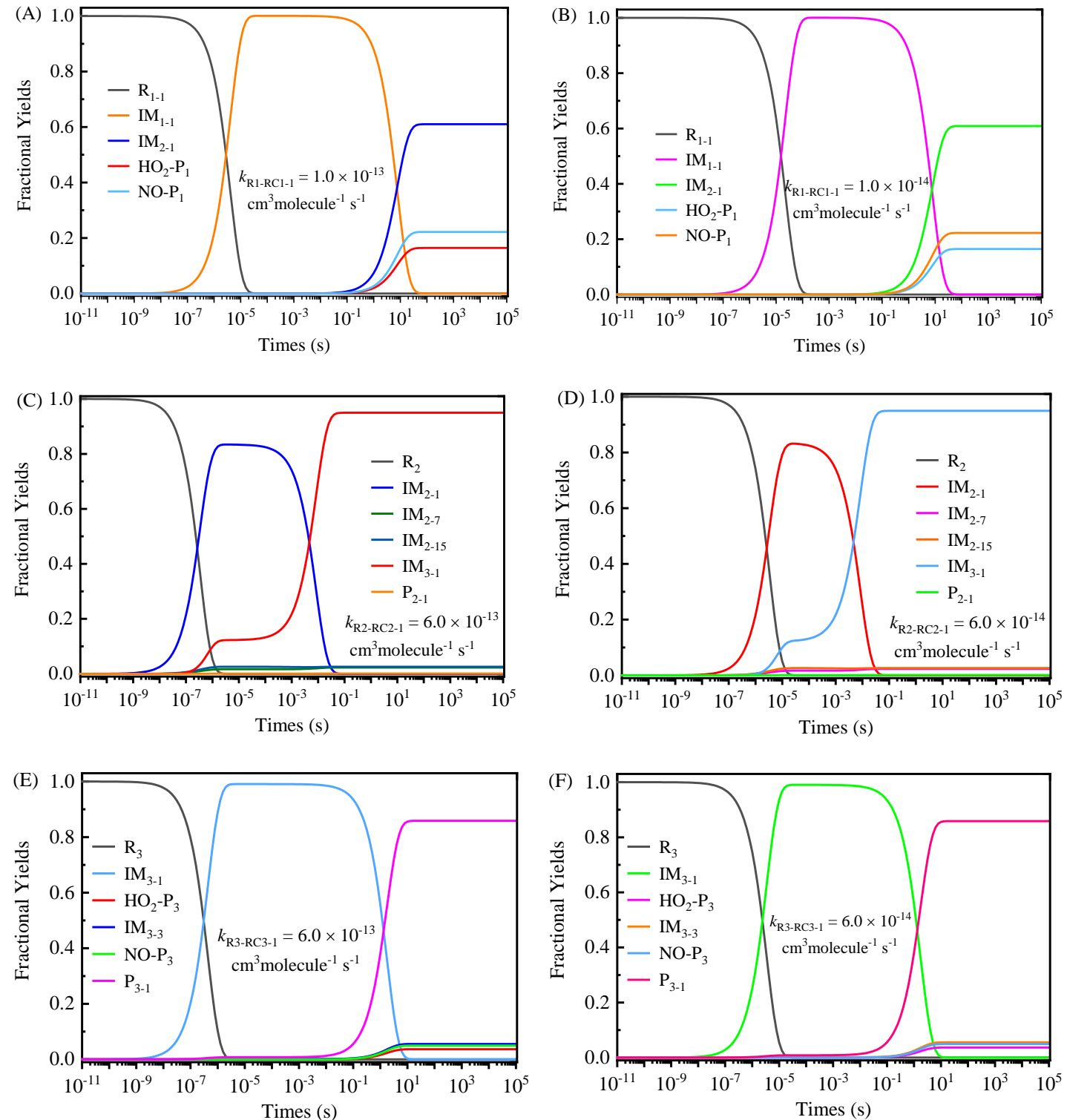

Figure S1. Under 100 ppt NO and 50 ppt $\mathrm{HO}_{2} \cdot$ conditions, calculated fractional yields as a function of time in the reactions of $\cdot \mathrm{C}_{5} \mathrm{H}_{7}\left(\mathrm{R}_{1}\right) / \mathrm{IM}_{1-7}\left(\mathrm{R}_{2}\right) / \mathrm{IM}_{2-6}\left(\mathrm{R}_{3}\right)$ with $\mathrm{O}_{2}$ at 298 $\mathrm{K}$ and 760 Torr with various $\mathrm{O}_{2}$ addition rates within ILT treatment. The symbols "NO$\mathrm{P}_{1 / 3}$ and $\mathrm{HO}_{2}-\mathrm{P}_{1 / 3}$ stand for the products from the reactions of $\mathrm{IM}_{1-1} / \mathrm{IM}_{3-1}$ with $\mathrm{NO}$ and $\mathrm{HO}_{2}$, respectively. The species with a fractional yield less than $1 \%$ were not presented. 
J. Schematic ZPE-corrected potential surface of self-isomerization/dissociation reaction for $\mathrm{IM}_{1-7}$

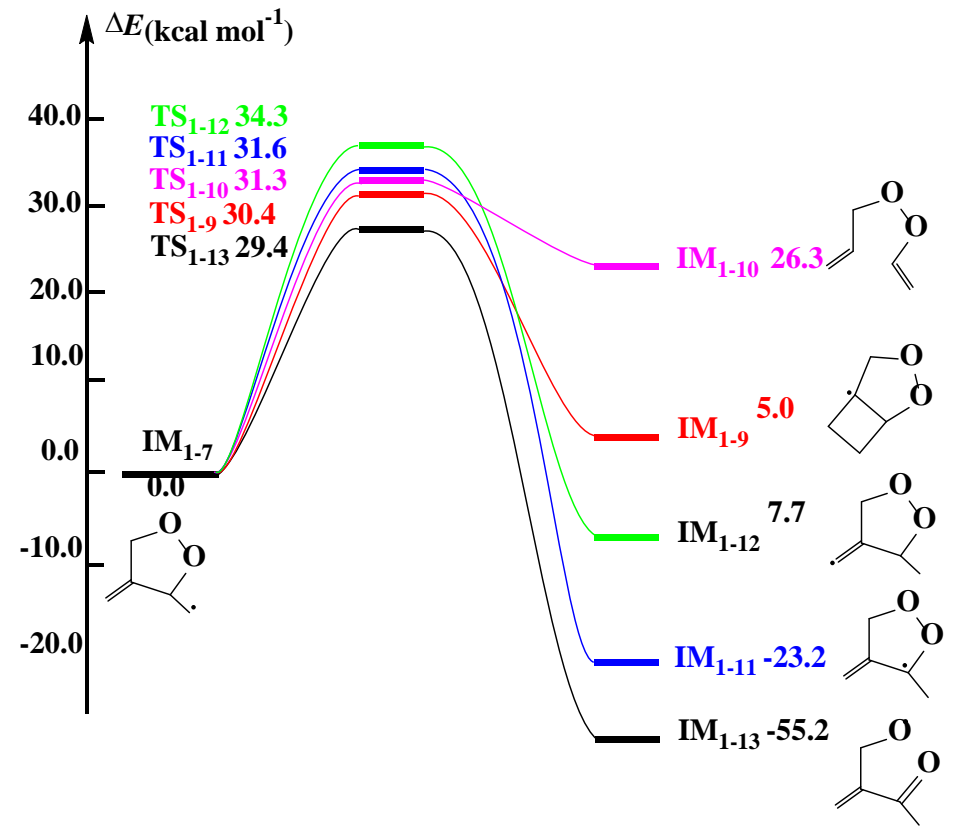

Figure S2. Schematic ZPE-corrected potential energy surfaces of selfisomerization/dissociation reaction for IM1-7 at the CBS-QB3//M06-2X/6-31+G(3df,2p) level of theory. The total energy of the $\mathrm{IM}_{1-7}$ is set as zero (reference state). 
K. Schematic ZPE-corrected potential energy surfaces for $\mathrm{IM}_{1-7}+\mathrm{O}_{2}$ reaction and self-isomerization/dissociation reaction of $\mathrm{IM}_{2-6}$
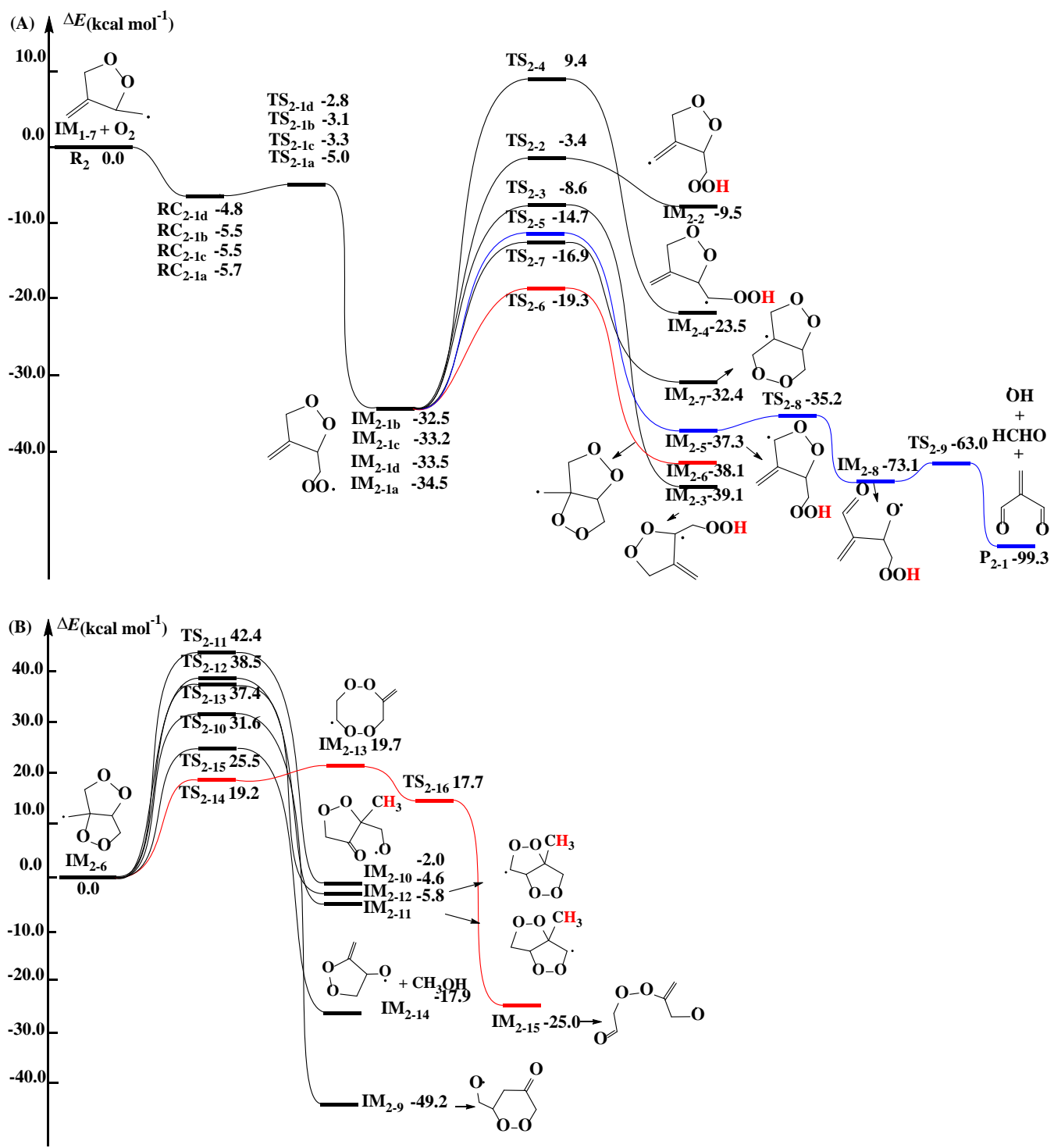

Figure S3. Schematic ZPE-corrected potential energy surfaces for $\mathrm{IM}_{1-7}+\mathrm{O}_{2}$ reaction (A) and self-isomerization/dissociation reaction of IM2-6 (B) at the CBS-QB3//M062X/6-31+G(3df,2p) level of theory. The total energies of the $\mathrm{IM}_{1-7}+\mathrm{O}_{2}$ and $\mathrm{IM}_{2-6}$ are set as zero (reference state), respectively. 
L. Time-dependence of fractional yields in the $\mathrm{IM}_{1-7}+\mathrm{O}_{2}$ reactions

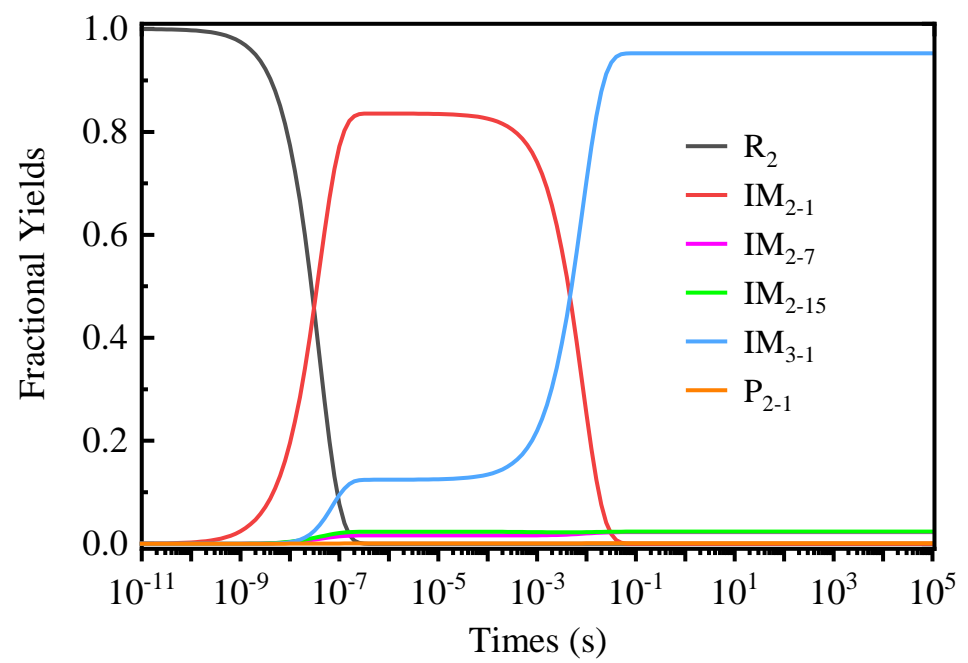

Figure S4. Under $100 \mathrm{ppt} \mathrm{NO}$ and $50 \mathrm{ppt} \mathrm{HO}_{2} \cdot$ conditions, calculated fractional yields as a function of time in the reaction of $\mathrm{IM}_{1-7}$ with $\mathrm{O}_{2}$ at $298 \mathrm{~K}$ and 760 Torr. The species with a fractional yield less than $1 \%$ were not presented. 
M. Schematic ZPE-corrected potential energy surfaces for $\mathrm{IM}_{2-6}+\mathrm{O}_{2}$ reaction

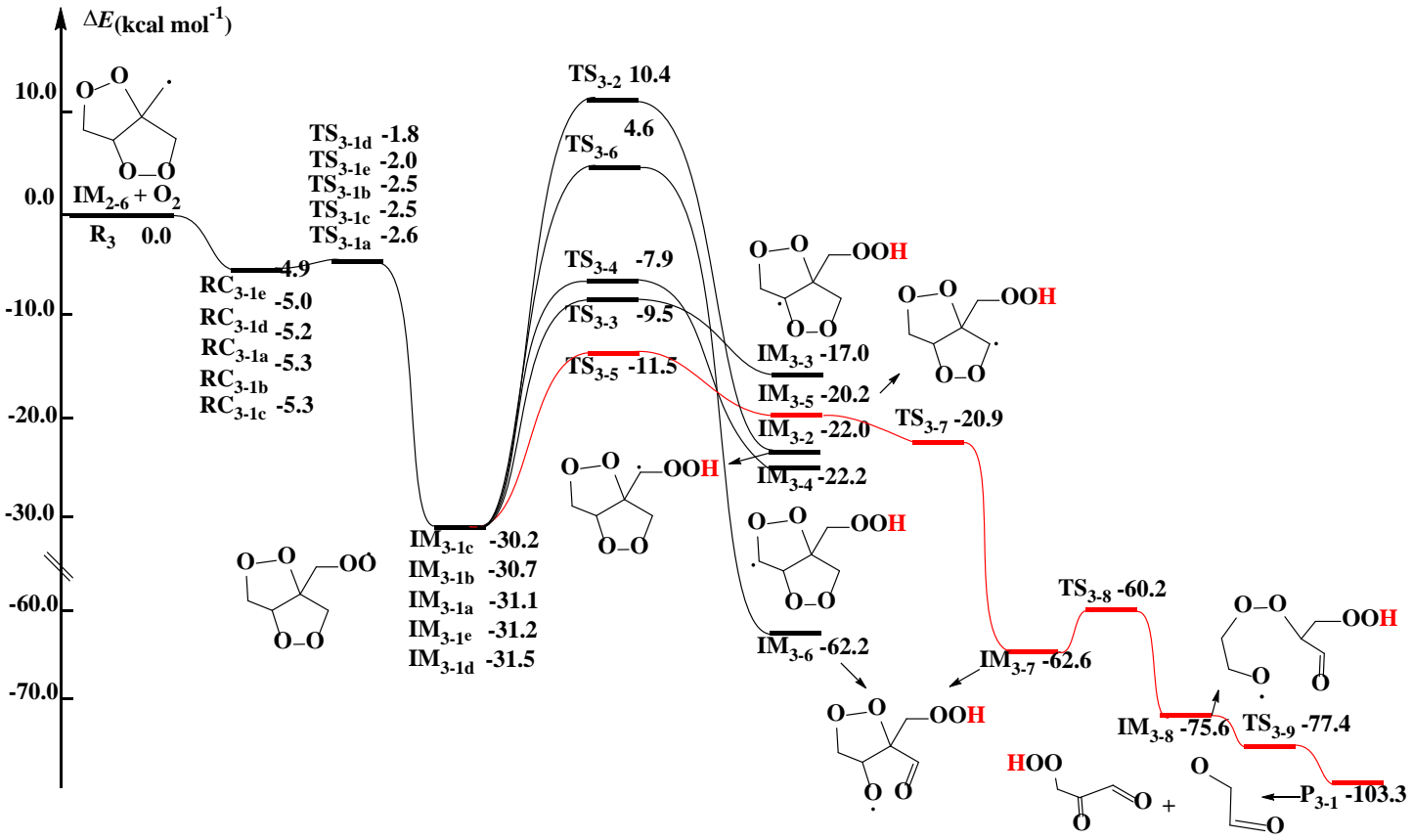

Figure S5. Schematic ZPE-corrected potential energy surface for the reaction of IM2-6 with $\mathrm{O}_{2}$ at the CBS-QB3//M06-2X/6-31+G(3df,2p) level of theory. The total energy of the reactants $\mathrm{IM}_{2-6}+\mathrm{O}_{2}$ is set as zero (reference state). 
N. Optimized geometries for the intermediates and transition states involved in the main atmospheric oxidation pathways of $\cdot \mathrm{C}_{5} \mathrm{H}_{7}$

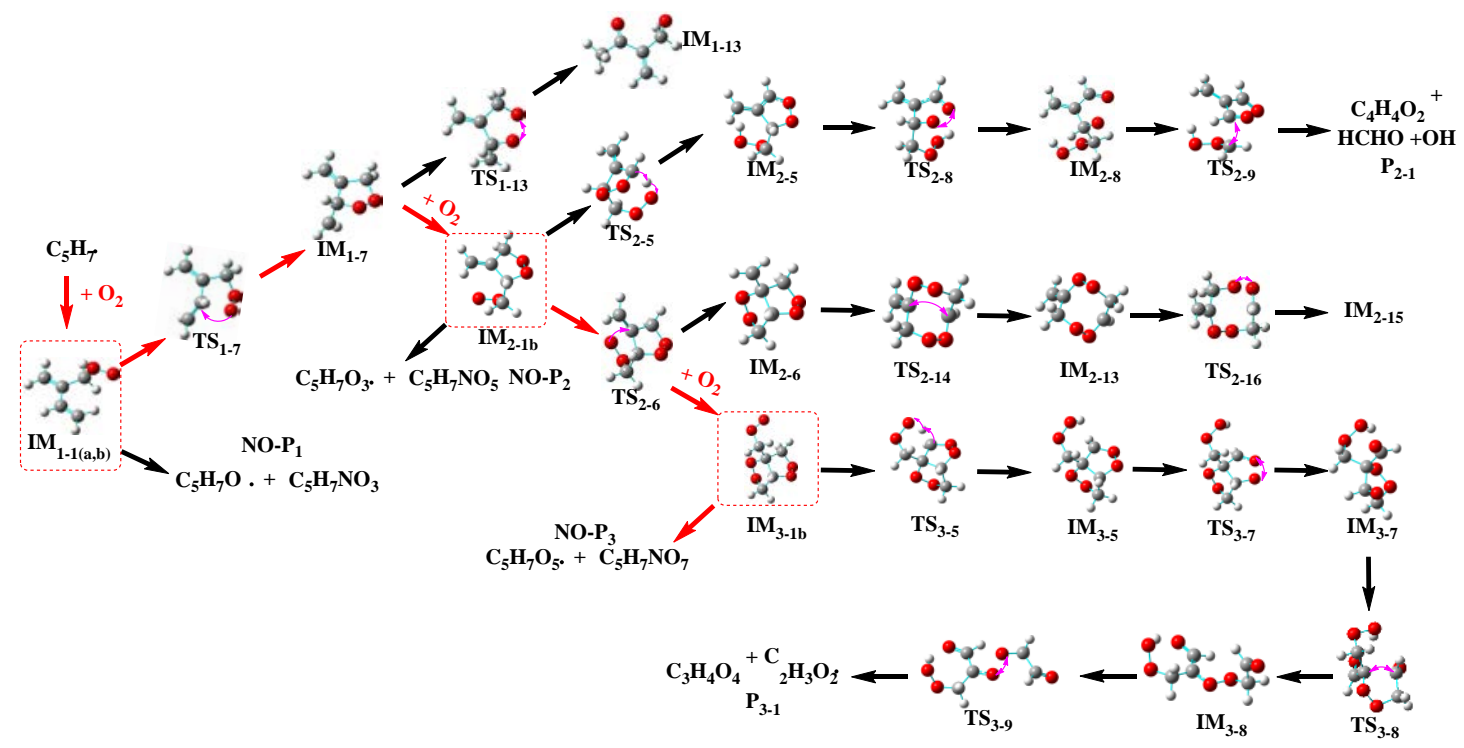

Figure S6. Optimized geometries of the intermediates and transition states involved in the main atmospheric oxidation pathways of $\cdot \mathrm{C}_{5} \mathrm{H} 7$. The white balls represent $\mathrm{H}$ atoms; the gray ones for $\mathrm{C}$ atoms and the red ones for $\mathrm{O}$ atoms.

\section{O. T1 diagnostics values for the selected intermediates and transition states}

Table S7. Values of $\mathrm{T}_{1}$ diagnostics for the intermediates and transition states involved in the important reaction pathways in the $\operatorname{CCSD}(\mathrm{T}) / 6-31+\mathrm{G}(\mathrm{d})$ calculations within the CBS-QB3 scheme.

\begin{tabular}{lccc}
\hline Species & $\mathrm{T}_{1}$ Diagnostics & Species & $\mathrm{T}_{1}$ Diagnostics \\
\hline IM $_{1-1 \mathrm{~b}}$ & 0.022 & $\mathrm{TS}_{1-1 \mathrm{~b}}$ & 0.042 \\
IM $_{1-7}$ & 0.016 & $\mathrm{TS}_{1-7}$ & 0.033 \\
IM$_{1-8}$ & 0.022 & $\mathrm{TS}_{1-8}$ & 0.038 \\
$\mathrm{IM}_{2-1 \mathrm{a}}$ & 0.021 & $\mathrm{TS}_{2-5}$ & 0.029 \\
IM$_{2-5}$ & 0.023 & $\mathrm{TS}_{2-6}$ & 0.029 \\
IM$_{2-6}$ & 0.015 & $\mathrm{TS}_{2-7}$ & 0.028 \\
IM$_{2-7}$ & 0.016 & $\mathrm{TS}_{3-3}$ & 0.023 \\
IM$_{3-1 \mathrm{~b}}$ & 0.021 & $\mathrm{TS}_{3-5}$ & 0.021 \\
IM$_{3-3}$ & 0.022 & & \\
IM$_{3-5}$ & 0.018 & & \\
\hline
\end{tabular}




\section{P. Lennard-Jones parameters used in the MESMER simulations}

Table S8. Lennard-Jones parameters of intermediates for various reactions used in the

MESMER simulations.

\begin{tabular}{lcc}
\hline Species & $\sigma /(\AA)$ & $\varepsilon /(\mathrm{K})$ \\
\hline $\mathrm{IM}_{1-1}$ and IM1-7 & 5.9 & 425 \\
$\mathrm{IM}_{2-1}, \mathrm{IM}_{2-5}, \mathrm{IM}_{2-6}, \mathrm{IM}_{2-8}$ and $\mathrm{IM}_{2-13}$ & 6.3 & 503 \\
$\mathrm{IM}_{3-1}, \mathrm{IM}_{3-5}$ IM-7 and IM3-8 & 6.6 & 577 \\
\hline
\end{tabular}

\section{Q. Cartesian coordinates of the transition states for all reactions}

Table S9. Cartesian coordinates of the transition states for all reactions.

\begin{tabular}{ccrrr}
\hline Species & Atoms & $\mathrm{X}$ & $\mathrm{Y}$ & $\mathrm{Z}$ \\
\hline TS1-1a & $\mathrm{C}$ & -1.35661700 & 0.99579300 & -0.12813900 \\
& $\mathrm{C}$ & -1.04441300 & -0.41783400 & 0.15926600 \\
& $\mathrm{C}$ & 0.11773600 & -0.74736400 & 0.92101000 \\
& $\mathrm{H}$ & -2.33272300 & 1.17485000 & -0.57205400 \\
& $\mathrm{C}$ & -0.53799500 & 2.02556800 & 0.08246000 \\
& $\mathrm{C}$ & -1.83570400 & -1.39734800 & -0.34758400 \\
& $\mathrm{H}$ & 0.32756500 & -1.78710000 & 1.13777800 \\
& $\mathrm{H}$ & 0.60189000 & -0.00894400 & 1.54573500 \\
& $\mathrm{H}$ & -0.83831700 & 3.03514000 & -0.17067200 \\
& $\mathrm{H}$ & 0.45733400 & 1.90165500 & 0.49623700 \\
$\mathrm{H}$ & -1.62220700 & -2.44386600 & -0.16404300 \\
& $\mathrm{H}$ & -2.70538300 & -1.16090200 & -0.94951700 \\
& $\mathrm{O}$ & 1.64971500 & -0.53454700 & -0.53488600 \\
& $\mathrm{O}$ & 2.60701000 & 0.10158100 & -0.14580600 \\
& & & & \\
& $\mathrm{C}$ & 1.63562400 & 0.25011000 & -0.38734200 \\
& $\mathrm{C}$ & 0.41875400 & 0.62579300 & 0.35996400 \\
& $\mathrm{C}$ & -0.18636300 & -0.26129700 & 1.27864200 \\
& $\mathrm{H}$ & 1.99856500 & 1.00717800 & -1.07822100 \\
& $\mathrm{C}$ & 2.29428000 & -0.90350400 & -0.29612300 \\
& $\mathrm{C}$ & -0.23674600 & 1.77471800 & 0.03578800 \\
$\mathrm{H}$ & -0.98804300 & 0.09482700 & 1.91201100 \\
& $\mathrm{H}$ & 0.27299100 & -1.19968200 & 1.55828500 \\
$\mathrm{H}$ & 3.17650900 & -1.08769300 & -0.89694000 \\
& $\mathrm{H}$ & 1.98427300 & -1.70355500 & 0.36684500
\end{tabular}




\begin{tabular}{|c|c|c|c|c|}
\hline & $\mathrm{H}$ & -1.14184000 & 2.06772300 & 0.55407500 \\
\hline & $\mathrm{H}$ & 0.13392000 & 2.43865100 & -0.73672200 \\
\hline & $\mathrm{O}$ & -1.63870600 & -1.07905700 & -0.07597500 \\
\hline & $\mathrm{O}$ & -1.98500200 & -0.23748900 & -0.87713800 \\
\hline $\mathrm{TS}_{1-2}$ & $\mathrm{C}$ & 1.85253100 & 0.47787300 & -0.05765800 \\
\hline & $\mathrm{C}$ & 0.38175700 & 0.43707100 & -0.02002600 \\
\hline & $\mathrm{C}$ & -0.31510700 & -0.91414600 & 0.10726700 \\
\hline & $\mathrm{H}$ & 2.28988400 & 1.46418600 & -0.18212200 \\
\hline & $\mathrm{C}$ & 2.64922500 & -0.58374300 & 0.07441400 \\
\hline & $\mathrm{C}$ & -0.36761200 & 1.52296200 & -0.06209800 \\
\hline & $\mathrm{H}$ & -0.33606400 & -1.22826000 & 1.15829600 \\
\hline & $\mathrm{H}$ & 0.18338600 & -1.67447000 & -0.49728100 \\
\hline & $\mathrm{H}$ & 3.72657300 & -0.47285600 & 0.05565400 \\
\hline & $\mathrm{H}$ & 2.26548100 & -1.58822600 & 0.21310900 \\
\hline & $\mathrm{H}$ & -1.70564000 & 1.02699600 & 0.07643900 \\
\hline & $\mathrm{H}$ & -0.14991700 & 2.58219100 & -0.11613900 \\
\hline & $\mathrm{O}$ & -1.61783500 & -0.83754100 & -0.41708200 \\
\hline & $\mathrm{O}$ & -2.31697400 & 0.11883300 & 0.29716300 \\
\hline $\mathrm{TS}_{1-3}$ & $\mathrm{C}$ & 0.86434600 & -0.67798600 & -0.05128500 \\
\hline & $\mathrm{C}$ & 0.44765600 & 0.70223400 & 0.07546100 \\
\hline & $\mathrm{C}$ & -0.99624600 & 0.85853700 & 0.50319800 \\
\hline & $\mathrm{H}$ & -0.34453800 & -1.30698400 & -0.24502400 \\
\hline & $\mathrm{C}$ & 1.97811900 & -1.36252300 & 0.12141200 \\
\hline & $\mathrm{C}$ & 1.21504700 & 1.74322400 & -0.26895700 \\
\hline & $\mathrm{H}$ & -1.35032600 & 1.88071800 & 0.36352700 \\
\hline & $\mathrm{H}$ & -1.15441000 & 0.53345700 & 1.53717400 \\
\hline & $\mathrm{H}$ & 2.88223900 & -0.86908400 & 0.47865000 \\
\hline & $\mathrm{H}$ & 2.03888500 & -2.42751200 & -0.07159900 \\
\hline & $\mathrm{H}$ & 0.84959100 & 2.76120600 & -0.18572500 \\
\hline & $\mathrm{H}$ & 2.22698700 & 1.59859000 & -0.63031100 \\
\hline & $\mathrm{O}$ & -1.77886400 & 0.05025200 & -0.36464600 \\
\hline & $\mathrm{O}$ & -1.49638100 & -1.26916600 & -0.07606200 \\
\hline $\mathrm{TS}_{1-4}$ & $\mathrm{C}$ & -0.65576600 & 1.31399600 & -0.01990100 \\
\hline & $\mathrm{C}$ & -1.04681900 & -0.10420700 & 0.05806000 \\
\hline & $\mathrm{C}$ & -0.00325600 & -1.16473700 & 0.31448100 \\
\hline & $\mathrm{H}$ & -1.48197400 & 2.01823400 & -0.14858900 \\
\hline & $\mathrm{C}$ & 0.57107300 & 1.80120600 & 0.02918400 \\
\hline & $\mathrm{C}$ & -2.33227500 & -0.44380000 & -0.07426500 \\
\hline & $\mathrm{H}$ & -0.41171900 & -2.14831100 & 0.07081500 \\
\hline & $\mathrm{H}$ & 0.31993900 & -1.15968500 & 1.36053100 \\
\hline & $\mathrm{H}$ & 0.94797500 & 2.81576100 & -0.01398100 \\
\hline
\end{tabular}




\begin{tabular}{|c|c|c|c|c|}
\hline & $\mathrm{H}$ & 1.58158900 & 0.81056100 & 0.07316900 \\
\hline & $\mathrm{H}$ & -2.64998300 & -1.48022000 & -0.04156500 \\
\hline & $\mathrm{H}$ & -3.10244200 & 0.30727300 & -0.21288800 \\
\hline & $\mathrm{O}$ & 1.14666800 & -1.01126200 & -0.50681700 \\
\hline & $\mathrm{O}$ & 2.05319100 & -0.18603300 & 0.14021200 \\
\hline $\mathrm{TS}_{1-5}$ & $\mathrm{C}$ & 1.88776000 & 0.12916600 & 0.06167800 \\
\hline & $\mathrm{C}$ & 0.49368600 & 0.57819200 & -0.06238000 \\
\hline & $\mathrm{C}$ & -0.52787700 & -0.42529900 & -0.40754600 \\
\hline & $\mathrm{H}$ & 2.61931000 & 0.92317000 & 0.18630800 \\
\hline & $\mathrm{C}$ & 2.29608300 & -1.14007800 & 0.05278500 \\
\hline & $\mathrm{C}$ & 0.14474900 & 1.85744200 & 0.14593700 \\
\hline & $\mathrm{H}$ & -0.90144000 & -1.08558200 & 0.63973100 \\
\hline & $\mathrm{H}$ & -0.27296000 & -1.20246600 & -1.13110200 \\
\hline & $\mathrm{H}$ & 3.34506600 & -1.38715700 & 0.16058100 \\
\hline & $\mathrm{H}$ & 1.60853300 & -1.97282300 & -0.05003600 \\
\hline & $\mathrm{H}$ & -0.88873300 & 2.17270400 & 0.07690500 \\
\hline & $\mathrm{H}$ & 0.89638300 & 2.59960200 & 0.39032600 \\
\hline & $\mathrm{O}$ & -1.83489800 & 0.01544900 & -0.52027200 \\
\hline & $\mathrm{O}$ & -2.18667300 & -0.77094700 & 0.64332900 \\
\hline $\mathrm{TS}_{1-6}$ & $\mathrm{C}$ & -1.50048500 & 0.37677200 & 0.20173900 \\
\hline & $\mathrm{C}$ & -0.09135000 & 0.44408300 & -0.21652900 \\
\hline & $\mathrm{C}$ & 0.63098400 & -0.75317800 & -0.82760600 \\
\hline & $\mathrm{H}$ & -1.87459700 & 1.27049000 & 0.69534200 \\
\hline & $\mathrm{C}$ & -2.32170200 & -0.65280800 & 0.00677600 \\
\hline & $\mathrm{C}$ & 0.48635600 & 1.69825800 & -0.36981000 \\
\hline & $\mathrm{H}$ & 1.01268900 & -0.59459200 & -1.83871200 \\
\hline & $\mathrm{H}$ & 0.03394600 & -1.66833200 & -0.78526500 \\
\hline & $\mathrm{H}$ & -3.35192900 & -0.60692400 & 0.33878000 \\
\hline & $\mathrm{H}$ & -2.00953900 & -1.56588700 & -0.48586100 \\
\hline & $\mathrm{H}$ & 1.48186200 & 1.79840700 & -0.78355800 \\
\hline & $\mathrm{H}$ & 0.00220000 & 2.58067100 & 0.02899700 \\
\hline & $\mathrm{O}$ & 1.69810500 & -0.80571800 & 0.10244300 \\
\hline & $\mathrm{O}$ & 0.98721300 & -0.18085700 & 1.15541400 \\
\hline $\mathrm{TS}_{1-7}$ & $\mathrm{C}$ & 0.39446000 & 0.88083600 & 0.49674700 \\
\hline & $\mathrm{C}$ & 0.68906900 & -0.54223200 & 0.17073400 \\
\hline & $\mathrm{C}$ & -0.58633000 & -1.34810400 & 0.08073500 \\
\hline & $\mathrm{H}$ & 0.28444200 & 1.12980300 & 1.54828500 \\
\hline & $\mathrm{C}$ & 0.71604800 & 1.88754500 & -0.38660700 \\
\hline & $\mathrm{C}$ & 1.90373500 & -1.02496000 & -0.06410800 \\
\hline & $\mathrm{H}$ & -0.94573000 & -1.63795300 & 1.07525600 \\
\hline & $\mathrm{H}$ & -0.49755000 & -2.22217600 & -0.56548100 \\
\hline
\end{tabular}




\begin{tabular}{|c|c|c|c|c|}
\hline & $\mathrm{H}$ & 0.65810500 & 2.92748100 & -0.09301300 \\
\hline & $\mathrm{H}$ & 0.93465100 & 1.65820400 & -1.42238800 \\
\hline & $\mathrm{H}$ & 2.05270400 & -2.06855600 & -0.32057400 \\
\hline & $\mathrm{H}$ & 2.78460400 & -0.39726800 & 0.00653700 \\
\hline & $\mathrm{O}$ & -1.51495900 & -0.46209300 & -0.51760000 \\
\hline & $\mathrm{O}$ & -1.48168000 & 0.64858800 & 0.26589700 \\
\hline $\mathrm{TS}_{1-8}$ & $\mathrm{C}$ & -0.22794 & 1.261064 & -0.296545 \\
\hline & $\mathrm{C}$ & -1.05246 & 0.066403 & -0.064466 \\
\hline & $\mathrm{C}$ & -0.272529 & -1.238244 & -0.212966 \\
\hline & $\mathrm{H}$ & -0.456699 & 1.887503 & -1.152773 \\
\hline & $\mathrm{C}$ & 0.977009 & 1.402316 & 0.353871 \\
\hline & $\mathrm{C}$ & -2.363825 & 0.064274 & 0.16675 \\
\hline & $\mathrm{H}$ & -0.145709 & -1.46903 & -1.276285 \\
\hline & $\mathrm{H}$ & -0.776813 & -2.063104 & 0.294004 \\
\hline & $\mathrm{H}$ & 1.652078 & 2.198528 & 0.058991 \\
\hline & $\mathrm{H}$ & 1.126109 & 0.995648 & 1.345569 \\
\hline & $\mathrm{H}$ & -2.908934 & -0.863872 & 0.303468 \\
\hline & $\mathrm{H}$ & -2.927586 & 0.988008 & 0.231116 \\
\hline & $\mathrm{O}$ & 1.005584 & -1.134192 & 0.386322 \\
\hline & $\mathrm{O}$ & 1.753918 & -0.241878 & -0.321816 \\
\hline $\mathrm{TS}_{1-9}$ & $\mathrm{C}$ & 0.23601400 & -0.80038200 & -0.56320600 \\
\hline & $\mathrm{C}$ & 0.41899900 & 0.69616400 & -0.50408300 \\
\hline & $\mathrm{C}$ & -0.89861100 & 1.21148100 & -0.02596700 \\
\hline & $\mathrm{H}$ & 0.44227600 & -1.33517000 & -1.49118800 \\
\hline & $\mathrm{C}$ & 1.20015400 & -1.07115400 & 0.57921100 \\
\hline & $\mathrm{C}$ & 1.68087200 & 0.93461200 & 0.01052600 \\
\hline & $\mathrm{H}$ & -1.52921100 & 1.56316300 & -0.85193200 \\
\hline & $\mathrm{H}$ & -0.82506100 & 1.97904100 & 0.74684400 \\
\hline & $\mathrm{H}$ & 2.01591000 & -1.77807400 & 0.45323800 \\
\hline & $\mathrm{H}$ & 0.75590100 & -1.00163400 & 1.56614800 \\
\hline & $\mathrm{H}$ & 1.88942700 & 1.80937900 & 0.62511400 \\
\hline & $\mathrm{H}$ & 2.55258700 & 0.50490800 & -0.46927100 \\
\hline & $\mathrm{O}$ & -1.49842000 & 0.06765000 & 0.58637400 \\
\hline & $\mathrm{O}$ & -1.14238000 & -1.01339300 & -0.28110300 \\
\hline $\mathrm{TS}_{1-10}$ & $\mathrm{C}$ & 0.96167000 & 0.78747600 & -0.49932000 \\
\hline & $\mathrm{C}$ & -1.16403200 & 0.08609400 & -0.09396300 \\
\hline & $\mathrm{C}$ & -0.68478500 & -1.28330600 & 0.18630100 \\
\hline & $\mathrm{H}$ & 0.75780200 & 1.25501500 & -1.45759900 \\
\hline & $\mathrm{C}$ & 1.21733300 & 1.48857700 & 0.62580300 \\
\hline & $\mathrm{C}$ & -2.27388800 & 0.78128100 & -0.08559400 \\
\hline & $\mathrm{H}$ & -0.89066500 & -1.94842400 & -0.65966300 \\
\hline & $\mathrm{H}$ & -1.11541700 & -1.69852300 & 1.10277300 \\
\hline
\end{tabular}




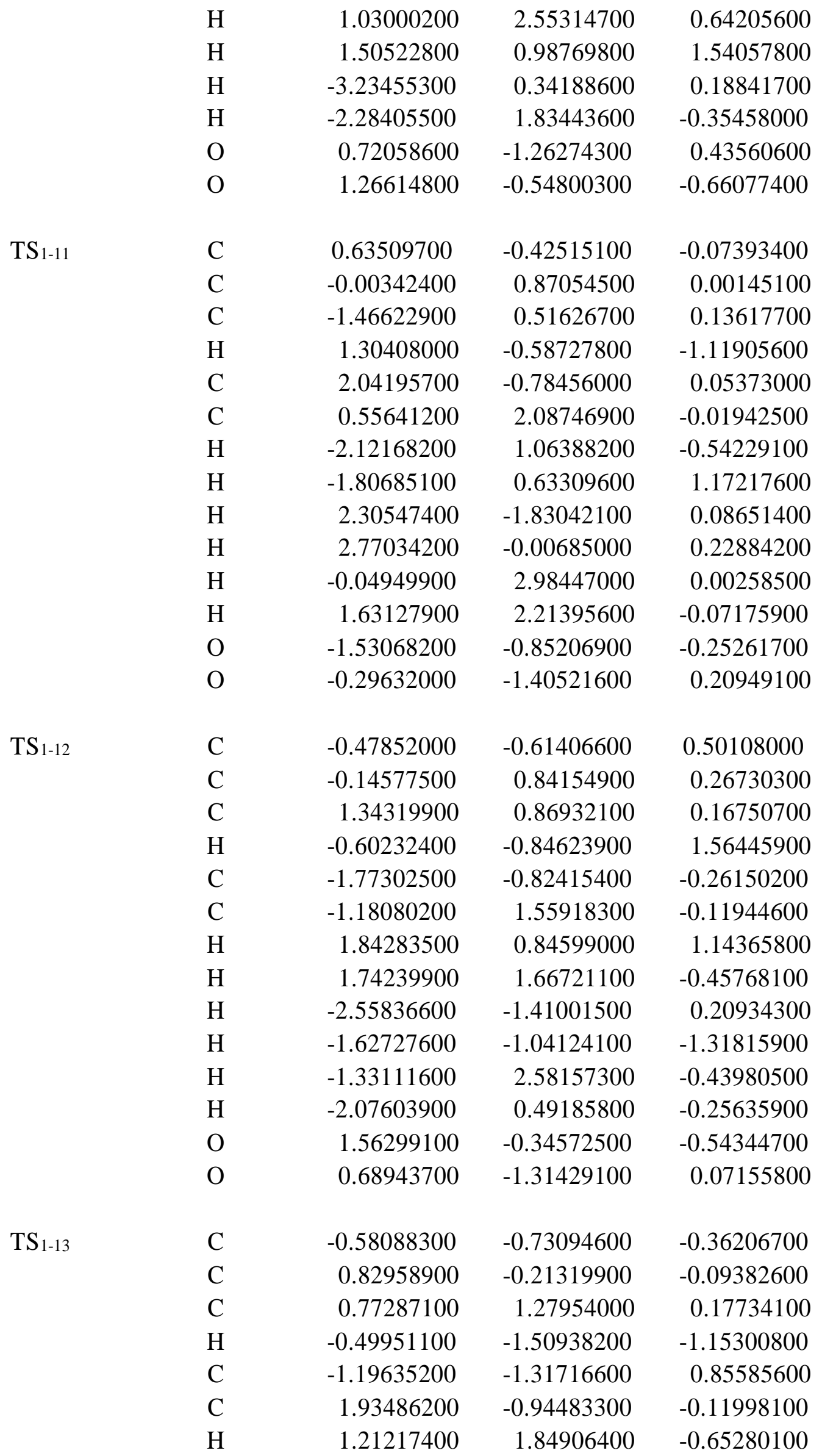




\begin{tabular}{|c|c|c|c|c|}
\hline & $\mathrm{H}$ & 1.34565100 & 1.51388600 & 1.09095300 \\
\hline & $\mathrm{H}$ & -2.20706400 & -1.04173800 & 1.12377800 \\
\hline & $\mathrm{H}$ & -0.68345500 & -2.10607500 & 1.38864200 \\
\hline & $\mathrm{H}$ & 2.90317800 & -0.51382600 & 0.11246100 \\
\hline & $\mathrm{H}$ & 1.91246800 & -1.99823200 & -0.37738300 \\
\hline & $\mathrm{O}$ & -0.51035500 & 1.68217500 & 0.45446800 \\
\hline & $\mathrm{O}$ & -1.30764000 & 0.23856600 & -0.98904000 \\
\hline $\mathrm{TS}_{2-1 \mathrm{a}}$ & $\mathrm{C}$ & 0.05053600 & 0.15541700 & -0.12940700 \\
\hline & $\mathrm{C}$ & -1.36871900 & 0.70068600 & -0.14674100 \\
\hline & $\mathrm{C}$ & -2.22686600 & -0.53987500 & -0.10245500 \\
\hline & $\mathrm{H}$ & 0.65511300 & 0.57190700 & -0.94760000 \\
\hline & $\mathrm{C}$ & 0.71507200 & 0.32781200 & 1.18413500 \\
\hline & $\mathrm{C}$ & -1.74805600 & 1.96853700 & -0.19272400 \\
\hline & $\mathrm{H}$ & -2.66817000 & -0.75022700 & -1.08360700 \\
\hline & $\mathrm{H}$ & -3.00184800 & -0.51222500 & 0.66490900 \\
\hline & $\mathrm{H}$ & 0.75297000 & -0.51625200 & 1.85892100 \\
\hline & $\mathrm{H}$ & 0.87551200 & 1.32439000 & 1.57389700 \\
\hline & $\mathrm{H}$ & -2.79570700 & 2.24726700 & -0.18168000 \\
\hline & $\mathrm{H}$ & -1.02240400 & 2.77282600 & -0.24541000 \\
\hline & $\mathrm{O}$ & -1.31918500 & -1.56857400 & 0.26080800 \\
\hline & $\mathrm{O}$ & -0.13040200 & -1.22038900 & -0.44727600 \\
\hline & $\mathrm{O}$ & 2.90243900 & 0.13001300 & -0.83956600 \\
\hline & $\mathrm{O}$ & 2.88123900 & 0.05730700 & 0.36150000 \\
\hline $\mathrm{TS}_{2-1 \mathrm{~b}}$ & $\mathrm{C}$ & 0.71928100 & -0.21688800 & 1.04732000 \\
\hline & $\mathrm{C}$ & 0.66526500 & 0.97774300 & 0.11363800 \\
\hline & $\mathrm{C}$ & 1.07512900 & 0.40485800 & -1.22130600 \\
\hline & $\mathrm{H}$ & 1.27240500 & 0.01507800 & 1.96678100 \\
\hline & $\mathrm{C}$ & -0.63208400 & -0.77449200 & 1.34552600 \\
\hline & $\mathrm{C}$ & 0.33894000 & 2.22378500 & 0.41693100 \\
\hline & $\mathrm{H}$ & 2.07193900 & 0.75299500 & -1.51510800 \\
\hline & $\mathrm{H}$ & 0.35181900 & 0.59898900 & -2.01533700 \\
\hline & $\mathrm{H}$ & -0.73398400 & -1.84906400 & 1.42815800 \\
\hline & $\mathrm{H}$ & -1.34406500 & -0.14445500 & 1.86452700 \\
\hline & $\mathrm{H}$ & 0.31074500 & 3.00246400 & -0.33689200 \\
\hline & $\mathrm{H}$ & 0.08401600 & 2.50840600 & 1.43188100 \\
\hline & $\mathrm{O}$ & 1.08347700 & -1.00025800 & -1.01097700 \\
\hline & $\mathrm{O}$ & 1.53371100 & -1.13895000 & 0.33668400 \\
\hline & $\mathrm{O}$ & -2.74898300 & 0.11409600 & -0.41604500 \\
\hline & $\mathrm{O}$ & -1.74471300 & -0.54669400 & -0.53924400 \\
\hline $\mathrm{TS}_{2-1 \mathrm{c}}$ & $\mathrm{C}$ & 0.10887600 & -0.32228200 & 0.64385000 \\
\hline & $\mathrm{C}$ & 0.84253200 & 0.90581300 & 0.15266600 \\
\hline
\end{tabular}




\begin{tabular}{|c|c|c|c|c|}
\hline & $\mathrm{C}$ & 2.14303100 & 0.35871000 & -0.38456100 \\
\hline & $\mathrm{H}$ & -0.22956500 & -0.22720600 & 1.67864700 \\
\hline & $\mathrm{C}$ & -1.04437500 & -0.75061500 & -0.25927900 \\
\hline & $\mathrm{C}$ & 0.42882800 & 2.16334000 & 0.18247000 \\
\hline & $\mathrm{H}$ & 2.96950100 & 0.52375400 & 0.31614000 \\
\hline & $\mathrm{H}$ & 2.40299000 & 0.73465700 & -1.37492300 \\
\hline & $\mathrm{H}$ & -1.50701100 & -1.66971600 & 0.10001400 \\
\hline & $\mathrm{H}$ & -0.70030200 & -0.86757200 & -1.28973400 \\
\hline & $\mathrm{H}$ & 1.03797400 & 2.96417800 & -0.22177500 \\
\hline & $\mathrm{H}$ & -0.53193500 & 2.43172200 & 0.60578300 \\
\hline & $\mathrm{O}$ & 1.88657600 & -1.03136800 & -0.52325900 \\
\hline & $\mathrm{O}$ & 1.10510700 & -1.33470800 & 0.63288600 \\
\hline & $\mathrm{O}$ & -3.24194000 & -0.17552700 & -0.10402400 \\
\hline & $\mathrm{O}$ & -2.03912000 & 0.28915100 & -0.23373100 \\
\hline $\mathrm{TS}_{2-1 \mathrm{~d}}$ & $\mathrm{C}$ & -0.27464900 & -0.52571900 & -0.51728800 \\
\hline & $\mathrm{C}$ & -0.64889600 & 0.89627100 & -0.15745700 \\
\hline & $\mathrm{C}$ & -2.08253200 & 0.79378900 & 0.30495400 \\
\hline & $\mathrm{H}$ & 0.11673800 & -0.61111500 & -1.53666100 \\
\hline & $\mathrm{C}$ & 0.65153200 & -1.16739500 & 0.46045100 \\
\hline & $\mathrm{C}$ & 0.11542600 & 1.97561900 & -0.22555600 \\
\hline & $\mathrm{H}$ & -2.77757300 & 1.15549800 & -0.46197200 \\
\hline & $\mathrm{H}$ & -2.27366100 & 1.29339300 & 1.25570700 \\
\hline & $\mathrm{H}$ & 0.91001200 & -2.20788900 & 0.30890400 \\
\hline & $\mathrm{H}$ & 0.77425800 & -0.74743400 & 1.45001900 \\
\hline & $\mathrm{H}$ & -0.25450900 & 2.94694000 & 0.08347600 \\
\hline & $\mathrm{H}$ & 1.13320900 & 1.92646600 & -0.59512100 \\
\hline & $\mathrm{O}$ & -2.26755800 & -0.59664400 & 0.52057200 \\
\hline & $\mathrm{O}$ & -1.54854900 & -1.18679200 & -0.55960000 \\
\hline & $\mathrm{O}$ & 2.51635900 & -0.31673100 & -0.36773100 \\
\hline & $\mathrm{O}$ & 3.27552700 & 0.15126200 & 0.44488800 \\
\hline $\mathrm{TS}_{2-2}$ & $\mathrm{C}$ & -0.14730000 & -0.51055100 & -0.62499700 \\
\hline & $\mathrm{C}$ & -0.38356800 & 0.91693100 & -0.16545900 \\
\hline & $\mathrm{C}$ & -1.83996500 & 0.92673400 & 0.25183000 \\
\hline & $\mathrm{H}$ & 0.15106800 & -0.53901300 & -1.67407700 \\
\hline & $\mathrm{C}$ & 0.84862800 & -1.28520800 & 0.25027200 \\
\hline & $\mathrm{C}$ & 0.53861300 & 1.84636900 & -0.10543600 \\
\hline & $\mathrm{H}$ & -2.48844900 & 1.28645900 & -0.55490900 \\
\hline & $\mathrm{H}$ & -2.02727000 & 1.47256400 & 1.17612700 \\
\hline & $\mathrm{H}$ & 1.25005100 & -2.13940400 & -0.30363900 \\
\hline & $\mathrm{H}$ & 0.33866100 & -1.63132200 & 1.15228300 \\
\hline & $\mathrm{H}$ & 0.55150500 & 2.88248000 & 0.20662300 \\
\hline & $\mathrm{H}$ & 1.76668700 & 1.19568100 & -0.31946900 \\
\hline
\end{tabular}




\begin{tabular}{|c|c|c|c|c|}
\hline & $\mathrm{O}$ & -2.08721200 & -0.44349700 & 0.51623500 \\
\hline & $\mathrm{O}$ & -1.44248700 & -1.09988400 & -0.57249400 \\
\hline & $\mathrm{O}$ & 2.41683700 & 0.27290000 & -0.33104300 \\
\hline & $\mathrm{O}$ & 1.90777500 & -0.46615600 & 0.72227900 \\
\hline $\mathrm{TS}_{2-3}$ & $\mathrm{C}$ & 0.12264300 & -0.16365500 & -0.02802200 \\
\hline & $\mathrm{C}$ & -0.96953400 & 0.82314100 & -0.01251000 \\
\hline & $\mathrm{C}$ & -2.19870700 & 0.00680500 & -0.30499400 \\
\hline & $\mathrm{H}$ & 0.96993400 & 0.07980000 & -0.99361900 \\
\hline & $\mathrm{C}$ & 1.31101700 & -0.07875900 & 0.95690200 \\
\hline & $\mathrm{C}$ & -0.87481800 & 2.13740000 & 0.18152700 \\
\hline & $\mathrm{H}$ & -2.41931500 & -0.01672100 & -1.37948300 \\
\hline & $\mathrm{H}$ & -3.07787500 & 0.31732500 & 0.25970700 \\
\hline & $\mathrm{H}$ & 1.37074600 & 0.94750500 & 1.33208900 \\
\hline & $\mathrm{H}$ & 1.24197700 & -0.80214800 & 1.76996700 \\
\hline & $\mathrm{H}$ & -1.75192300 & 2.77274200 & 0.15414200 \\
\hline & $\mathrm{H}$ & 0.08303700 & 2.61461800 & 0.35407100 \\
\hline & $\mathrm{O}$ & -1.84900600 & -1.28707500 & 0.15591700 \\
\hline & $\mathrm{O}$ & -0.44834900 & -1.41270500 & -0.13856000 \\
\hline & $\mathrm{O}$ & 2.26121600 & 0.31237700 & -0.97826400 \\
\hline & $\mathrm{O}$ & 2.44111500 & -0.39543600 & 0.17911900 \\
\hline $\mathrm{TS}_{2-4}$ & $\mathrm{C}$ & 0.09821700 & 0.31997800 & 0.69214600 \\
\hline & $\mathrm{C}$ & 1.43117600 & 0.52876900 & 0.01087100 \\
\hline & $\mathrm{C}$ & 1.85602200 & -0.86682400 & -0.37378300 \\
\hline & $\mathrm{H}$ & 0.04088400 & 0.77210800 & 1.68833900 \\
\hline & $\mathrm{C}$ & -1.05195700 & 0.81275500 & -0.15834100 \\
\hline & $\mathrm{C}$ & 2.05067600 & 1.67793800 & -0.21090200 \\
\hline & $\mathrm{H}$ & 2.60858400 & -1.26088600 & 0.31886200 \\
\hline & $\mathrm{H}$ & 2.20340200 & -0.95451300 & -1.40388700 \\
\hline & $\mathrm{H}$ & -0.93455300 & 1.76845700 & -0.67485400 \\
\hline & $\mathrm{H}$ & -1.36142900 & -0.08185700 & -1.07810000 \\
\hline & $\mathrm{H}$ & 2.99617900 & 1.71854000 & -0.73968900 \\
\hline & $\mathrm{H}$ & 1.63869400 & 2.61904300 & 0.13723600 \\
\hline & $\mathrm{O}$ & 0.65423400 & -1.61608000 & -0.27232300 \\
\hline & $\mathrm{O}$ & 0.03829900 & -1.08219300 & 0.89790000 \\
\hline & $\mathrm{O}$ & -2.56982900 & -0.32241900 & -0.73749600 \\
\hline & $\mathrm{O}$ & -2.30977500 & 0.59361900 & 0.36093700 \\
\hline $\mathrm{TS}_{2-5}$ & $\mathrm{C}$ & -0.24299100 & -0.21954900 & -1.08732200 \\
\hline & $\mathrm{C}$ & -1.19359900 & 0.33224500 & -0.05691800 \\
\hline & $\mathrm{C}$ & -0.71587900 & -0.35574500 & 1.15687700 \\
\hline & $\mathrm{H}$ & -0.67260300 & -0.25027400 & -2.09159600 \\
\hline & $\mathrm{C}$ & 1.12078800 & 0.49305900 & -1.10979500 \\
\hline
\end{tabular}




\begin{tabular}{|c|c|c|c|c|}
\hline & $\mathrm{C}$ & -2.14856500 & 1.24098700 & -0.20428900 \\
\hline & $\mathrm{H}$ & -1.35648300 & -0.49490300 & 2.02609000 \\
\hline & $\mathrm{H}$ & 0.27681900 & 0.42422300 & 1.44045800 \\
\hline & $\mathrm{H}$ & 0.98507800 & 1.55875500 & -1.32370500 \\
\hline & $\mathrm{H}$ & 1.75643200 & 0.02714400 & -1.86602600 \\
\hline & $\mathrm{H}$ & -2.75204100 & 1.56584100 & 0.63485300 \\
\hline & $\mathrm{H}$ & -2.34728600 & 1.69217700 & -1.16952000 \\
\hline & $\mathrm{O}$ & -0.13579400 & -1.54732300 & 0.75873600 \\
\hline & $\mathrm{O}$ & -0.08673500 & -1.56747900 & -0.67424900 \\
\hline & $\mathrm{O}$ & 1.29191700 & 1.10700700 & 1.08341700 \\
\hline & $\mathrm{O}$ & 1.82955700 & 0.32417700 & 0.10186100 \\
\hline $\mathrm{TS}_{2-6}$ & $\mathrm{C}$ & -0.00105700 & -0.36837200 & 1.00790700 \\
\hline & $\mathrm{C}$ & 0.43133800 & 0.82288900 & 0.16475700 \\
\hline & $\mathrm{C}$ & 1.22244800 & 0.17433500 & -0.95868600 \\
\hline & $\mathrm{H}$ & 0.07263900 & -0.19242500 & 2.08162800 \\
\hline & $\mathrm{C}$ & -1.41418700 & -0.80574700 & 0.57940200 \\
\hline & $\mathrm{C}$ & 0.69172300 & 2.08052600 & 0.64273500 \\
\hline & $\mathrm{H}$ & 2.26990700 & 0.49108900 & -0.92958400 \\
\hline & $\mathrm{H}$ & 0.78171200 & 0.35642400 & -1.93942500 \\
\hline & $\mathrm{H}$ & -1.50368400 & -1.89222300 & 0.55036700 \\
\hline & $\mathrm{H}$ & -2.16452000 & -0.35919000 & 1.23867300 \\
\hline & $\mathrm{H}$ & 1.28158500 & 2.78310200 & 0.06690900 \\
\hline & $\mathrm{H}$ & 0.23047700 & 2.43718400 & 1.55501100 \\
\hline & $\mathrm{O}$ & 1.11654400 & -1.22422800 & -0.71722700 \\
\hline & $\mathrm{O}$ & 0.98617200 & -1.33528000 & 0.69876200 \\
\hline & $\mathrm{O}$ & -1.32972100 & 1.00204600 & -0.65007900 \\
\hline & $\mathrm{O}$ & -1.59170800 & -0.32325600 & -0.73649100 \\
\hline $\mathrm{TS}_{2-7}$ & $\mathrm{C}$ & 0.41868400 & -0.54192300 & 0.90073100 \\
\hline & $\mathrm{C}$ & 0.13096800 & 0.87496800 & 0.52096000 \\
\hline & $\mathrm{C}$ & 1.19380700 & 1.21632800 & -0.48037900 \\
\hline & $\mathrm{H}$ & 0.44215600 & -0.74826900 & 1.97414200 \\
\hline & $\mathrm{C}$ & -0.63333600 & -1.44897600 & 0.19037900 \\
\hline & $\mathrm{C}$ & -1.12014400 & 1.42143700 & 0.64350800 \\
\hline & $\mathrm{H}$ & 1.94821200 & 1.89354100 & -0.05859000 \\
\hline & $\mathrm{H}$ & 0.79140600 & 1.62726300 & -1.40933100 \\
\hline & $\mathrm{H}$ & -0.12737400 & -2.32250700 & -0.22550000 \\
\hline & $\mathrm{H}$ & -1.41525300 & -1.74606500 & 0.89539400 \\
\hline & $\mathrm{H}$ & -1.34711100 & 2.36155200 & 0.15319200 \\
\hline & $\mathrm{H}$ & -1.73287200 & 1.17462300 & 1.50192700 \\
\hline & $\mathrm{O}$ & 1.77787600 & -0.03917400 & -0.80303400 \\
\hline & $\mathrm{O}$ & 1.73575900 & -0.76405400 & 0.42708600 \\
\hline & $\mathrm{O}$ & -2.10370300 & 0.15110400 & -0.41252100 \\
\hline
\end{tabular}




\begin{tabular}{|c|c|c|c|c|}
\hline & $\mathrm{O}$ & -1.22231300 & -0.76926900 & -0.89683500 \\
\hline \multirow[t]{16}{*}{$\mathrm{TS}_{2-8}$} & $\mathrm{C}$ & 0.10604100 & 0.25575700 & 1.02506600 \\
\hline & $\mathrm{C}$ & 1.19050400 & 0.49642400 & -0.02711600 \\
\hline & $\mathrm{C}$ & 1.44974800 & -0.79135400 & -0.58352800 \\
\hline & $\mathrm{H}$ & 0.45426600 & 0.68400800 & 1.97402000 \\
\hline & $\mathrm{C}$ & -1.26596700 & 0.86792900 & 0.69187700 \\
\hline & $\mathrm{C}$ & 1.79442900 & 1.66359000 & -0.29321500 \\
\hline & $\mathrm{H}$ & 2.37610500 & -1.12482600 & -1.04295300 \\
\hline & $\mathrm{H}$ & -1.04505300 & -0.78802300 & -1.49301400 \\
\hline & $\mathrm{H}$ & -1.12796200 & 1.88944400 & 0.31282600 \\
\hline & $\mathrm{H}$ & -1.87900600 & 0.89535600 & 1.59628000 \\
\hline & $\mathrm{H}$ & 2.53014200 & 1.75077800 & -1.08303700 \\
\hline & $\mathrm{H}$ & 1.55291300 & 2.55901500 & 0.26736200 \\
\hline & $\mathrm{O}$ & 0.58957200 & -1.68649700 & -0.21386700 \\
\hline & $\mathrm{O}$ & 0.02738200 & -1.13546300 & 1.19336400 \\
\hline & $\mathrm{O}$ & -1.39406700 & 0.11361100 & -1.45934300 \\
\hline & $\mathrm{O}$ & -2.03662800 & 0.10587200 & -0.19640300 \\
\hline \multirow[t]{16}{*}{$\mathrm{TS}_{2-9}$} & $\mathrm{C}$ & 0.46413600 & -0.48272200 & 1.17724700 \\
\hline & $\mathrm{C}$ & 0.81609500 & 0.70815800 & 0.32989700 \\
\hline & $\mathrm{C}$ & 1.42150500 & 0.52000200 & -1.02054300 \\
\hline & $\mathrm{H}$ & -0.27180100 & -0.25209400 & 1.97395900 \\
\hline & $\mathrm{C}$ & -1.10514600 & -1.21694800 & -0.10965800 \\
\hline & $\mathrm{C}$ & 0.60758100 & 1.95159500 & 0.76938100 \\
\hline & $\mathrm{H}$ & 1.85342700 & 1.44315300 & -1.45978500 \\
\hline & $\mathrm{H}$ & -1.93497100 & 1.35883200 & 0.13837100 \\
\hline & $\mathrm{H}$ & -1.74166600 & -1.62886200 & 0.66693900 \\
\hline & $\mathrm{H}$ & -0.49087500 & -1.85336700 & -0.73511700 \\
\hline & $\mathrm{H}$ & 0.90883600 & 2.81442600 & 0.18211900 \\
\hline & $\mathrm{H}$ & 0.14987900 & 2.14198800 & 1.73648800 \\
\hline & $\mathrm{O}$ & 1.42500000 & -0.51641000 & -1.62583500 \\
\hline & $\mathrm{O}$ & 1.20525500 & -1.45915400 & 1.26696400 \\
\hline & $\mathrm{O}$ & -2.47149200 & 0.56214600 & 0.01040500 \\
\hline & $\mathrm{O}$ & -1.62099500 & -0.19965600 & -0.82414800 \\
\hline \multirow[t]{8}{*}{$\mathrm{TS}_{2-10}$} & $\mathrm{C}$ & 0.06762900 & 0.37060700 & 1.01719100 \\
\hline & $\mathrm{C}$ & -0.28697200 & -0.91784900 & -0.19613500 \\
\hline & $\mathrm{C}$ & -1.19332100 & -0.03102400 & -1.06926900 \\
\hline & $\mathrm{H}$ & -0.01873500 & 0.15093700 & 2.08187800 \\
\hline & $\mathrm{C}$ & 1.54103200 & 0.61646000 & 0.59161200 \\
\hline & $\mathrm{C}$ & -0.91773200 & -1.72350600 & 0.83819200 \\
\hline & $\mathrm{H}$ & -2.25278400 & -0.27293900 & -0.94408800 \\
\hline & $\mathrm{H}$ & -0.87982300 & -0.11325300 & -2.10869600 \\
\hline
\end{tabular}




\begin{tabular}{|c|c|c|c|c|}
\hline & $\mathrm{H}$ & 1.62438200 & 1.71131000 & 0.69217300 \\
\hline & $\mathrm{H}$ & 2.16820400 & 0.11456100 & 1.34545300 \\
\hline & $\mathrm{H}$ & -1.86039500 & -1.40471500 & 1.26424600 \\
\hline & $\mathrm{H}$ & -0.35036300 & -2.51120800 & 1.31628100 \\
\hline & $\mathrm{O}$ & -0.96781300 & 1.32734000 & -0.69201000 \\
\hline & $\mathrm{O}$ & -0.90807300 & 1.26236500 & 0.72494300 \\
\hline & $\mathrm{O}$ & 0.84210900 & -1.29585400 & -0.70395000 \\
\hline & $\mathrm{O}$ & 1.82198900 & 0.26079700 & -0.67108300 \\
\hline $\mathrm{TS}_{2-11}$ & $\mathrm{C}$ & -0.02110800 & -0.28788800 & 0.91101000 \\
\hline & $\mathrm{C}$ & 0.02718800 & 0.78044800 & -0.17851400 \\
\hline & $\mathrm{C}$ & 1.30612300 & 0.40379700 & -0.92060300 \\
\hline & $\mathrm{H}$ & -0.02179300 & 0.85507900 & 1.71874500 \\
\hline & $\mathrm{C}$ & -1.33798900 & -0.98594500 & 0.62559900 \\
\hline & $\mathrm{C}$ & 0.02158200 & 1.93421300 & 0.80241200 \\
\hline & $\mathrm{H}$ & 2.13936400 & 1.06028500 & -0.64942800 \\
\hline & $\mathrm{H}$ & 1.15693500 & 0.38174000 & -2.00047300 \\
\hline & $\mathrm{H}$ & -1.26426900 & -2.06693700 & 0.74482300 \\
\hline & $\mathrm{H}$ & -2.16019200 & -0.57092900 & 1.21637400 \\
\hline & $\mathrm{H}$ & 0.94559200 & 2.48680400 & 0.94227500 \\
\hline & $\mathrm{H}$ & -0.90498800 & 2.49513500 & 0.87573000 \\
\hline & $\mathrm{O}$ & 1.57957000 & -0.93147600 & -0.51540600 \\
\hline & $\mathrm{O}$ & 1.16438500 & -0.96919100 & 0.87941100 \\
\hline & $\mathrm{O}$ & -1.18368100 & 0.65889400 & -0.89022600 \\
\hline & $\mathrm{O}$ & -1.54345200 & -0.72184400 & -0.75971200 \\
\hline $\mathrm{TS}_{2-12}$ & $\mathrm{C}$ & -0.22580500 & -0.49281900 & 0.91040700 \\
\hline & $\mathrm{C}$ & 0.28748800 & 0.71224400 & 0.10377500 \\
\hline & $\mathrm{C}$ & 1.18718500 & -0.00604200 & -0.88748200 \\
\hline & $\mathrm{H}$ & -0.14158800 & -0.39635500 & 1.99269400 \\
\hline & $\mathrm{C}$ & -1.67167700 & -0.56625600 & 0.41193800 \\
\hline & $\mathrm{C}$ & 1.36680400 & 1.59025800 & 0.67843800 \\
\hline & $\mathrm{H}$ & 2.14177600 & 0.64366300 & -0.09756700 \\
\hline & $\mathrm{H}$ & 1.23677000 & 0.32274100 & -1.92325900 \\
\hline & $\mathrm{H}$ & -1.94297500 & -1.56809000 & 0.07807300 \\
\hline & $\mathrm{H}$ & -2.36680600 & -0.20552400 & 1.17644100 \\
\hline & $\mathrm{H}$ & 1.53285500 & 1.60039400 & 1.75128500 \\
\hline & $\mathrm{H}$ & 1.50361200 & 2.53911500 & 0.16581700 \\
\hline & $\mathrm{O}$ & 1.02159300 & -1.36369800 & -0.78460900 \\
\hline & $\mathrm{O}$ & 0.60570200 & -1.58614100 & 0.56667000 \\
\hline & $\mathrm{O}$ & -0.86303000 & 1.36871800 & -0.36060400 \\
\hline & $\mathrm{O}$ & -1.71771700 & 0.28608800 & -0.72720000 \\
\hline $\mathrm{TS}_{2-13}$ & $\mathrm{C}$ & -0.05686900 & -0.55548700 & -0.80695000 \\
\hline
\end{tabular}




\begin{tabular}{|c|c|c|c|c|}
\hline & $\mathrm{C}$ & -0.00075300 & 0.73177500 & 0.02136500 \\
\hline & $\mathrm{C}$ & -1.46287000 & 0.91040900 & 0.38183600 \\
\hline & $\mathrm{H}$ & -0.28923200 & -0.37164700 & -1.86076400 \\
\hline & $\mathrm{C}$ & 1.39296600 & -0.86125100 & -0.56041700 \\
\hline & $\mathrm{C}$ & 0.92702800 & 1.62439900 & -0.74012300 \\
\hline & $\mathrm{H}$ & -1.94170100 & 1.70061200 & -0.19866500 \\
\hline & $\mathrm{H}$ & -1.58799500 & 1.08281800 & 1.45290000 \\
\hline & $\mathrm{H}$ & 1.93377500 & -1.71591700 & -0.95405400 \\
\hline & $\mathrm{H}$ & 1.71600600 & 0.39038700 & -1.02746500 \\
\hline & $\mathrm{H}$ & 0.59105300 & 1.97607500 & -1.71227500 \\
\hline & $\mathrm{H}$ & 1.53852000 & 2.30981200 & -0.16369300 \\
\hline & $\mathrm{O}$ & -2.09048800 & -0.33086100 & 0.00080100 \\
\hline & $\mathrm{O}$ & -1.04489700 & -1.30599300 & -0.16391400 \\
\hline & $\mathrm{O}$ & 0.68403800 & 0.30039700 & 1.20889900 \\
\hline & $\mathrm{O}$ & 1.60666900 & -0.72244400 & 0.79043300 \\
\hline $\mathrm{TS}_{2-14}$ & $\mathrm{C}$ & -0.83266800 & -0.00045400 & 1.08216100 \\
\hline & $\mathrm{C}$ & 1.10064100 & -0.06111300 & -0.01718400 \\
\hline & $\mathrm{C}$ & 0.48643300 & -1.16233700 & -0.85402800 \\
\hline & $\mathrm{H}$ & -0.69367100 & -0.02402300 & 2.15591300 \\
\hline & $\mathrm{C}$ & -1.18225700 & 1.26644000 & 0.37790700 \\
\hline & $\mathrm{C}$ & 2.16079500 & -0.29748000 & 0.79830500 \\
\hline & $\mathrm{H}$ & 0.92264000 & -2.11772800 & -0.54843200 \\
\hline & $\mathrm{H}$ & 0.67887500 & -0.97276700 & -1.91258700 \\
\hline & $\mathrm{H}$ & -2.21285600 & 1.26201200 & 0.00760700 \\
\hline & $\mathrm{H}$ & -1.02192200 & 2.11187300 & 1.05402600 \\
\hline & $\mathrm{H}$ & 2.45962500 & -1.31174500 & 1.02118800 \\
\hline & $\mathrm{H}$ & 2.70312200 & 0.52380800 & 1.24727300 \\
\hline & $\mathrm{O}$ & -0.93169200 & -1.23575500 & -0.77602900 \\
\hline & $\mathrm{O}$ & -1.26390500 & -1.19293200 & 0.61120700 \\
\hline & $\mathrm{O}$ & 0.94626700 & 1.24152300 & -0.44505200 \\
\hline & $\mathrm{O}$ & -0.40485500 & 1.44444400 & -0.80862000 \\
\hline $\mathrm{TS}_{2-15}$ & $\mathrm{C}$ & 0.16151300 & -0.23935000 & 1.02976900 \\
\hline & $\mathrm{C}$ & -0.77735200 & 0.61851200 & 0.18702500 \\
\hline & $\mathrm{C}$ & 0.97776300 & 0.92044700 & -1.14650200 \\
\hline & $\mathrm{H}$ & -0.02091800 & -0.11250000 & 2.09691300 \\
\hline & $\mathrm{C}$ & -0.19851900 & -1.63077400 & 0.50685900 \\
\hline & $\mathrm{C}$ & -1.24107200 & 1.85936000 & 0.48735100 \\
\hline & $\mathrm{H}$ & 1.21153200 & 1.96529400 & -0.96239800 \\
\hline & $\mathrm{H}$ & 0.63224400 & 0.59111200 & -2.11969400 \\
\hline & $\mathrm{H}$ & 0.68286500 & -2.25217700 & 0.35063400 \\
\hline & $\mathrm{H}$ & -0.92497500 & -2.12416300 & 1.16019200 \\
\hline & $\mathrm{H}$ & -0.71819300 & 2.45288800 & 1.22458200 \\
\hline
\end{tabular}




\begin{tabular}{|c|c|c|c|c|}
\hline & $\mathrm{H}$ & -2.06064400 & 2.29992400 & -0.06369800 \\
\hline & $\mathrm{O}$ & 1.77375800 & 0.00682600 & -0.53822700 \\
\hline & $\mathrm{O}$ & 1.51818500 & 0.11462100 & 0.87594000 \\
\hline & $\mathrm{O}$ & -1.55883300 & -0.22359700 & -0.57608700 \\
\hline & $\mathrm{O}$ & -0.77509900 & -1.39654300 & -0.77081900 \\
\hline $\mathrm{TS}_{2-16}$ & $\mathrm{C}$ & 1.14420000 & 0.04372800 & 1.08494400 \\
\hline & $\mathrm{C}$ & -1.24533500 & -0.08224500 & -0.01767800 \\
\hline & $\mathrm{C}$ & -0.74535100 & 1.14818300 & -0.74559100 \\
\hline & $\mathrm{H}$ & 0.73217300 & -0.09092700 & 2.08289100 \\
\hline & $\mathrm{C}$ & 1.44223900 & -1.12828000 & 0.20421500 \\
\hline & $\mathrm{C}$ & -2.25295100 & -0.03340100 & 0.85420800 \\
\hline & $\mathrm{H}$ & -1.27658500 & 2.00707700 & -0.32110100 \\
\hline & $\mathrm{H}$ & -1.00936700 & 1.04900800 & -1.80736100 \\
\hline & $\mathrm{H}$ & 2.40448300 & -1.00114900 & -0.30139000 \\
\hline & $\mathrm{H}$ & 1.44159500 & -2.04623600 & 0.79886400 \\
\hline & $\mathrm{H}$ & -2.71292300 & 0.91354600 & 1.09849800 \\
\hline & $\mathrm{H}$ & -2.64570200 & -0.93847400 & 1.29962300 \\
\hline & $\mathrm{O}$ & 0.63517000 & 1.38542400 & -0.79837800 \\
\hline & $\mathrm{O}$ & 1.24563400 & 1.25730700 & 0.66236100 \\
\hline & $\mathrm{O}$ & -0.78291300 & -1.32996500 & -0.36789700 \\
\hline & $\mathrm{O}$ & 0.52829700 & -1.26036000 & -0.88741300 \\
\hline $\mathrm{TS}_{3-1 \mathrm{a}}$ & $\mathrm{C}$ & 1.36855000 & 0.10176400 & 0.91722500 \\
\hline & $\mathrm{C}$ & -0.02751600 & -0.11637400 & 0.24398200 \\
\hline & $\mathrm{C}$ & -0.02098400 & 1.06791900 & -0.74446500 \\
\hline & $\mathrm{H}$ & 1.36634500 & 0.06354500 & 2.00601400 \\
\hline & $\mathrm{C}$ & 2.18106400 & -1.01232200 & 0.25618200 \\
\hline & $\mathrm{C}$ & -1.20655300 & -0.16223800 & 1.13152100 \\
\hline & $\mathrm{H}$ & -0.67890700 & 1.87019700 & -0.39470000 \\
\hline & $\mathrm{H}$ & -0.29376400 & 0.74476900 & -1.74892300 \\
\hline & $\mathrm{H}$ & 3.13867500 & -0.64798900 & -0.11643400 \\
\hline & $\mathrm{H}$ & 2.31650100 & -1.85683000 & 0.93966800 \\
\hline & $\mathrm{H}$ & -1.51946700 & 0.75026300 & 1.62135800 \\
\hline & $\mathrm{H}$ & -1.49708700 & -1.11095500 & 1.56261600 \\
\hline & $\mathrm{O}$ & 1.32176400 & 1.51878800 & -0.79241500 \\
\hline & $\mathrm{O}$ & 1.74723600 & 1.40835700 & 0.56339700 \\
\hline & $\mathrm{O}$ & 0.08195300 & -1.38172600 & -0.38649900 \\
\hline & $\mathrm{O}$ & 1.41729700 & -1.41440200 & -0.87121600 \\
\hline & $\mathrm{O}$ & -2.76415400 & -0.08462200 & -0.39377900 \\
\hline & $\mathrm{O}$ & -3.87905300 & 0.06791800 & 0.04347900 \\
\hline $\mathrm{TS}_{3-1 \mathrm{~b}}$ & $\mathrm{C}$ & 1.40091200 & 0.05800500 & 0.83436700 \\
\hline & $\mathrm{C}$ & -0.09545500 & -0.05455400 & 0.37885300 \\
\hline
\end{tabular}




\begin{tabular}{|c|c|c|c|c|}
\hline & $\mathrm{C}$ & -0.13410900 & 1.09931500 & -0.64753400 \\
\hline & $\mathrm{H}$ & 1.55638600 & 0.01854700 & 1.91191300 \\
\hline & C & 2.01557500 & -1.11988200 & 0.07382200 \\
\hline & $\mathrm{C}$ & -1.10179300 & 0.02089200 & 1.45591200 \\
\hline & $\mathrm{H}$ & -0.69821100 & 1.95279000 & -0.25651500 \\
\hline & $\mathrm{H}$ & -0.53586600 & 0.76721300 & -1.60310500 \\
\hline & $\mathrm{H}$ & 2.92031600 & -0.82775800 & -0.45988100 \\
\hline & $\mathrm{H}$ & 2.20569300 & -1.96351400 & 0.74497600 \\
\hline & $\mathrm{H}$ & -1.26832800 & 0.97761100 & 1.93264000 \\
\hline & $\mathrm{H}$ & -1.32608500 & -0.87916900 & 2.01249000 \\
\hline & $\mathrm{O}$ & 1.21933900 & 1.46176300 & -0.87053200 \\
\hline & $\mathrm{O}$ & 1.81838700 & 1.33061000 & 0.41505300 \\
\hline & $\mathrm{O}$ & -0.18174800 & -1.34124500 & -0.20841600 \\
\hline & $\mathrm{O}$ & 1.05014700 & -1.48153000 & -0.90249100 \\
\hline & $\mathrm{O}$ & -2.98042500 & 0.00592500 & 0.32966300 \\
\hline & $\mathrm{O}$ & -2.84628600 & 0.01593000 & -0.87015900 \\
\hline TS $3-1 \mathrm{c}$ & C & -1.14164400 & 0.00134300 & 0.96170200 \\
\hline & C & 0.13338100 & -0.01802900 & 0.08161400 \\
\hline & C & -0.22980900 & -1.14264200 & -0.90398500 \\
\hline & $\mathrm{H}$ & -0.96854000 & 0.01005600 & 2.03857700 \\
\hline & C & -1.83099700 & 1.26255000 & 0.43649800 \\
\hline & $\mathrm{C}$ & 1.42634700 & -0.23774700 & 0.82872800 \\
\hline & $\mathrm{H}$ & 0.32043900 & -2.06241800 & -0.67987200 \\
\hline & $\mathrm{H}$ & -0.07062600 & -0.83344400 & -1.93657300 \\
\hline & $\mathrm{H}$ & -2.88110600 & 1.08236400 & 0.20600500 \\
\hline & $\mathrm{H}$ & -1.71572400 & 2.09556900 & 1.13725700 \\
\hline & $\mathrm{H}$ & 1.34609700 & -1.12643000 & 1.46043200 \\
\hline & $\mathrm{H}$ & 1.71165800 & 0.63754800 & 1.41294700 \\
\hline & $\mathrm{O}$ & -1.62315900 & -1.35135000 & -0.73166000 \\
\hline & $\mathrm{O}$ & -1.80248200 & -1.20797700 & 0.67431300 \\
\hline & $\mathrm{O}$ & 0.18600700 & 1.26438600 & -0.50967200 \\
\hline & $\mathrm{O}$ & -1.17708500 & 1.56155900 & -0.78897500 \\
\hline & $\mathrm{O}$ & 2.47846100 & -0.49515200 & -0.12216700 \\
\hline & $\mathrm{O}$ & 3.45252300 & 0.35402200 & -0.03010200 \\
\hline TS 3 -1d & $\mathrm{C}$ & -0.23878500 & 0.24677700 & 0.87056300 \\
\hline & C & -0.13987200 & -0.50600800 & -0.48895200 \\
\hline & C & -1.50181800 & -1.23947600 & -0.47970700 \\
\hline & $\mathrm{H}$ & 0.61015400 & 0.11214200 & 1.53955800 \\
\hline & C & -0.42602600 & 1.68314200 & 0.38806300 \\
\hline & C & 1.03463400 & -1.38413800 & -0.69758400 \\
\hline & $\mathrm{H}$ & -1.37997200 & -2.29066000 & -0.19617200 \\
\hline & $\mathrm{H}$ & -2.00392100 & -1.14221900 & -1.44235700 \\
\hline
\end{tabular}




\begin{tabular}{|c|c|c|c|c|}
\hline & $\mathrm{H}$ & -1.20181900 & 2.20600700 & 0.94743900 \\
\hline & $\mathrm{H}$ & 0.52293000 & 2.22938700 & 0.41623200 \\
\hline & $\mathrm{H}$ & 1.26190000 & -2.12856700 & 0.05488900 \\
\hline & $\mathrm{H}$ & 1.37941300 & -1.55529300 & -1.70890000 \\
\hline & $\mathrm{O}$ & -2.28510700 & -0.55951800 & 0.48163400 \\
\hline & $\mathrm{O}$ & -1.35324200 & -0.31032200 & 1.53079600 \\
\hline & $\mathrm{O}$ & -0.07471900 & 0.51705100 & -1.47041300 \\
\hline & $\mathrm{O}$ & -0.88229200 & 1.56453900 & -0.95147500 \\
\hline & $\mathrm{O}$ & 2.66864800 & 0.00057000 & -0.20155700 \\
\hline & $\mathrm{O}$ & 2.98202700 & 0.00860700 & 0.96539200 \\
\hline $\mathrm{TS}_{3-1 \mathrm{e}}$ & $\mathrm{C}$ & -0.46407400 & 0.21959500 & 0.93431200 \\
\hline & $\mathrm{C}$ & -0.11510700 & -0.48336400 & -0.41393900 \\
\hline & $\mathrm{C}$ & -1.45256700 & -1.21611600 & -0.67445800 \\
\hline & $\mathrm{H}$ & 0.26917100 & 0.08827500 & 1.72830100 \\
\hline & $\mathrm{C}$ & -0.62296400 & 1.66588500 & 0.46850600 \\
\hline & $\mathrm{C}$ & 1.08677000 & -1.34646900 & -0.43121700 \\
\hline & $\mathrm{H}$ & -1.36838900 & -2.28228300 & -0.43903300 \\
\hline & $\mathrm{H}$ & -1.79092900 & -1.06007400 & -1.69883300 \\
\hline & $\mathrm{H}$ & -1.51723700 & 2.13222600 & 0.88248900 \\
\hline & $\mathrm{H}$ & 0.27485400 & 2.24896400 & 0.69794500 \\
\hline & $\mathrm{H}$ & 1.13649100 & -2.17669900 & 0.26095300 \\
\hline & $\mathrm{H}$ & 1.68525200 & -1.38840500 & -1.33148400 \\
\hline & $\mathrm{O}$ & -2.39447000 & -0.59912400 & 0.18388600 \\
\hline & $\mathrm{O}$ & -1.64930400 & -0.39650300 & 1.38105000 \\
\hline & $\mathrm{O}$ & 0.12031000 & 0.57927400 & -1.32307000 \\
\hline & $\mathrm{O}$ & -0.80616700 & 1.58428000 & -0.93787500 \\
\hline & $\mathrm{O}$ & 2.46338400 & 0.02021800 & 0.57848200 \\
\hline & $\mathrm{O}$ & 3.60605100 & -0.01304400 & 0.19258000 \\
\hline $\mathrm{TS}_{3-2}$ & $\mathrm{C}$ & 0.36438500 & -0.10496400 & -0.94565700 \\
\hline & $\mathrm{C}$ & -0.08086000 & 0.02229500 & 0.53151400 \\
\hline & $\mathrm{C}$ & 0.75648200 & -1.08708700 & 1.18290600 \\
\hline & $\mathrm{H}$ & -0.45492200 & -0.15357000 & -1.66234200 \\
\hline & $\mathrm{C}$ & 1.24442500 & 1.13607500 & -1.08991600 \\
\hline & $\mathrm{C}$ & -1.55919100 & -0.08056100 & 0.76880400 \\
\hline & $\mathrm{H}$ & 0.14286400 & -1.96765800 & 1.40775700 \\
\hline & $\mathrm{H}$ & 1.27419100 & -0.73007400 & 2.07325000 \\
\hline & $\mathrm{H}$ & 2.19778100 & 0.90983400 & -1.56793300 \\
\hline & $\mathrm{H}$ & 0.70981200 & 1.93000100 & -1.61978500 \\
\hline & $\mathrm{H}$ & -2.04909400 & -1.13703800 & 0.14564600 \\
\hline & $\mathrm{H}$ & -1.92955300 & -0.12591200 & 1.79496500 \\
\hline & $\mathrm{O}$ & 1.74621900 & -1.41011500 & 0.22196400 \\
\hline & $\mathrm{O}$ & 1.03848500 & -1.34093800 & -1.01321400 \\
\hline
\end{tabular}




\begin{tabular}{|c|c|c|c|c|}
\hline & $\mathrm{O}$ & 0.30112100 & 1.32961000 & 0.92321100 \\
\hline & $\mathrm{O}$ & 1.53233500 & 1.54624000 & 0.24013400 \\
\hline & $\mathrm{O}$ & -2.34182900 & 0.67698400 & -0.08150600 \\
\hline & $\mathrm{O}$ & -2.80664700 & -0.55679700 & -0.69777200 \\
\hline $\mathrm{TS}_{3-3}$ & C & 0.19660700 & 0.10219800 & -0.83591600 \\
\hline & C & -0.00807700 & -0.23806600 & 0.64054900 \\
\hline & C & 1.03318200 & -1.34352700 & 0.82602200 \\
\hline & $\mathrm{H}$ & -1.01812500 & -0.16938600 & -1.34306500 \\
\hline & C & 0.45973300 & 1.59520100 & -0.80558300 \\
\hline & C & -1.45669200 & -0.61919900 & 0.97178500 \\
\hline & $\mathrm{H}$ & 0.56364300 & -2.33049100 & 0.74741400 \\
\hline & $\mathrm{H}$ & 1.58455300 & -1.24340300 & 1.76108700 \\
\hline & $\mathrm{H}$ & 1.16842800 & 1.91333600 & -1.56881400 \\
\hline & $\mathrm{H}$ & -0.47251300 & 2.16661400 & -0.84248400 \\
\hline & $\mathrm{H}$ & -1.62326100 & -1.68935900 & 0.82267600 \\
\hline & $\mathrm{H}$ & -1.70286900 & -0.32588200 & 1.99386500 \\
\hline & $\mathrm{O}$ & 1.96727200 & -1.16277300 & -0.22130300 \\
\hline & $\mathrm{O}$ & 1.17875700 & -0.70494900 & -1.34091700 \\
\hline & $\mathrm{O}$ & 0.26867400 & 0.97548700 & 1.32692400 \\
\hline & $\mathrm{O}$ & 1.09600100 & 1.74720500 & 0.45542700 \\
\hline & $\mathrm{O}$ & -2.31834300 & 0.11619100 & 0.13054600 \\
\hline & $\mathrm{O}$ & -2.17341000 & -0.38379500 & -1.14465500 \\
\hline $\mathrm{TS}_{3-4}$ & C & 0.40588600 & 0.51550000 & -0.83742800 \\
\hline & C & 0.18569100 & -0.62953000 & 0.15458100 \\
\hline & C & 1.54265700 & -1.30824100 & 0.08961000 \\
\hline & $\mathrm{H}$ & -0.00729000 & 0.32447800 & -1.82737100 \\
\hline & C & -0.35254200 & 1.59399200 & -0.11337200 \\
\hline & C & -1.07726700 & -1.45756100 & -0.08974600 \\
\hline & $\mathrm{H}$ & 1.61306200 & -1.97071400 & -0.78249400 \\
\hline & $\mathrm{H}$ & 1.80230600 & -1.83563100 & 1.00789100 \\
\hline & $\mathrm{H}$ & -0.20758000 & 2.64708700 & -0.34503300 \\
\hline & $\mathrm{H}$ & -1.54861800 & 1.17896200 & -0.47778700 \\
\hline & $\mathrm{H}$ & -1.07881300 & -1.87142400 & -1.10403600 \\
\hline & $\mathrm{H}$ & -1.14692000 & -2.26182500 & 0.64609500 \\
\hline & $\mathrm{O}$ & 2.42376600 & -0.21277900 & -0.01043200 \\
\hline & $\mathrm{O}$ & 1.81458100 & 0.65726900 & -0.96869700 \\
\hline & $\mathrm{O}$ & 0.09581800 & 0.00330100 & 1.42625900 \\
\hline & $\mathrm{O}$ & -0.21408300 & 1.38098600 & 1.23194300 \\
\hline & $\mathrm{O}$ & -2.22952300 & -0.67258700 & 0.13043700 \\
\hline & $\mathrm{O}$ & -2.34714700 & 0.28182400 & -0.85190100 \\
\hline $\mathrm{TS}_{3-5}$ & C & 1.00290900 & 0.26023800 & 0.95609300 \\
\hline
\end{tabular}




\begin{tabular}{|c|c|c|c|c|}
\hline & $\mathrm{C}$ & -0.07967000 & -0.41674700 & 0.09247300 \\
\hline & $\mathrm{C}$ & -0.37924000 & 0.71789700 & -0.88793800 \\
\hline & $\mathrm{H}$ & 0.88594400 & 0.13351800 & 2.03225700 \\
\hline & $\mathrm{C}$ & 2.27236700 & -0.37969000 & 0.38850300 \\
\hline & $\mathrm{C}$ & -1.34057500 & -0.93840600 & 0.78980800 \\
\hline & $\mathrm{H}$ & -1.62690200 & 0.99589400 & -0.57569600 \\
\hline & $\mathrm{H}$ & -0.39483800 & 0.45256400 & -1.94474600 \\
\hline & $\mathrm{H}$ & 3.03481400 & 0.36044800 & 0.14524300 \\
\hline & $\mathrm{H}$ & 2.66451400 & -1.14124600 & 1.06951200 \\
\hline & $\mathrm{H}$ & -1.50258600 & -0.41110500 & 1.73428100 \\
\hline & $\mathrm{H}$ & -1.25623200 & -2.01385100 & 0.95630500 \\
\hline & $\mathrm{O}$ & 0.50976700 & 1.74089300 & -0.66160700 \\
\hline & $\mathrm{O}$ & 0.86072200 & 1.64581300 & 0.71799500 \\
\hline & $\mathrm{O}$ & 0.58101200 & -1.51113000 & -0.51543900 \\
\hline & $\mathrm{O}$ & 1.86275000 & -0.98285300 & -0.83305900 \\
\hline & $\mathrm{O}$ & -2.45376800 & -0.74112000 & -0.05083500 \\
\hline & $\mathrm{O}$ & -2.69291500 & 0.61889900 & -0.08840300 \\
\hline $\mathrm{TS}_{3-6}$ & $\mathrm{C}$ & 1.20833500 & 0.07747500 & 0.92863000 \\
\hline & $\mathrm{C}$ & -0.15952800 & -0.20993000 & 0.27675900 \\
\hline & $\mathrm{C}$ & -0.49277300 & 1.15747400 & -0.28014100 \\
\hline & $\mathrm{H}$ & 1.22079700 & 0.08256700 & 2.01917200 \\
\hline & $\mathrm{C}$ & 2.09063700 & -0.96753000 & 0.27216100 \\
\hline & $\mathrm{C}$ & -1.38431500 & -0.76071600 & 1.00031200 \\
\hline & $\mathrm{H}$ & -1.12719000 & 1.79658200 & 0.34800100 \\
\hline & $\mathrm{H}$ & -1.50392700 & 0.71077100 & -1.06251700 \\
\hline & $\mathrm{H}$ & 3.12263700 & -0.63609000 & 0.16060200 \\
\hline & $\mathrm{H}$ & 2.03296200 & -1.92866400 & 0.79867500 \\
\hline & $\mathrm{H}$ & -1.37333100 & -0.56264900 & 2.07301700 \\
\hline & $\mathrm{H}$ & -1.49058500 & -1.82889800 & 0.79991800 \\
\hline & $\mathrm{O}$ & 0.69663100 & 1.71518900 & -0.64455200 \\
\hline & $\mathrm{O}$ & 1.55794600 & 1.39116100 & 0.48995000 \\
\hline & $\mathrm{O}$ & 0.14376800 & -1.15109900 & -0.75989300 \\
\hline & $\mathrm{O}$ & 1.53683700 & -1.06331000 & -1.02151600 \\
\hline & $\mathrm{O}$ & -2.52491900 & -0.04806200 & 0.50667000 \\
\hline & $\mathrm{O}$ & -2.46720000 & -0.02066100 & -0.86105900 \\
\hline $\mathrm{TS}_{3-7}$ & $\mathrm{C}$ & 1.16548700 & 0.23279700 & 0.88942700 \\
\hline & $\mathrm{C}$ & -0.04866700 & -0.26160500 & 0.05761600 \\
\hline & $\mathrm{C}$ & -0.19234000 & 0.86456300 & -0.91622300 \\
\hline & $\mathrm{H}$ & 1.01141000 & 0.15281700 & 1.96820000 \\
\hline & $\mathrm{C}$ & 2.26139500 & -0.69233300 & 0.36097800 \\
\hline & $\mathrm{C}$ & -1.28568100 & -0.60926500 & 0.88082200 \\
\hline & $\mathrm{H}$ & -2.70445400 & 0.76468000 & -0.88810500 \\
\hline
\end{tabular}




\begin{tabular}{|c|c|c|c|c|}
\hline & $\mathrm{H}$ & -0.23141400 & 0.69235300 & -1.98873900 \\
\hline & $\mathrm{H}$ & 3.19258000 & -0.16346000 & 0.15839100 \\
\hline & $\mathrm{H}$ & 2.42352900 & -1.53304200 & 1.04403200 \\
\hline & $\mathrm{H}$ & -1.48820300 & 0.18528100 & 1.60402800 \\
\hline & $\mathrm{H}$ & -1.10240400 & -1.55309000 & 1.40433900 \\
\hline & $\mathrm{O}$ & 0.42867800 & 1.96037100 & -0.50587200 \\
\hline & $\mathrm{O}$ & 1.36658600 & 1.59347700 & 0.58610200 \\
\hline & $\mathrm{O}$ & 0.40177500 & -1.44887300 & -0.57277900 \\
\hline & $\mathrm{O}$ & 1.76102900 & -1.16302700 & -0.88159500 \\
\hline & $\mathrm{O}$ & -2.42544700 & -0.82315400 & 0.08260400 \\
\hline & $\mathrm{O}$ & -3.09539700 & 0.41239600 & -0.07569300 \\
\hline \multirow[t]{18}{*}{$\mathrm{TS}_{3-8}$} & $\mathrm{C}$ & -0.79797500 & 0.94539500 & -0.76430000 \\
\hline & $\mathrm{C}$ & -0.08113600 & -0.64042000 & 0.10631100 \\
\hline & $\mathrm{C}$ & 0.17743600 & -0.15492400 & 1.51045100 \\
\hline & $\mathrm{H}$ & -0.29437200 & 0.74253300 & -1.72485800 \\
\hline & $\mathrm{C}$ & -2.24419500 & 0.44047500 & -0.64068900 \\
\hline & $\mathrm{C}$ & 1.07649500 & -1.23869800 & -0.68046500 \\
\hline & $\mathrm{H}$ & 1.95743000 & 1.15242100 & 0.01705400 \\
\hline & $\mathrm{H}$ & -0.53445600 & -0.54628400 & 2.25967500 \\
\hline & $\mathrm{H}$ & -2.88515400 & 1.23328100 & -0.25439900 \\
\hline & $\mathrm{H}$ & -2.61433800 & 0.05586600 & -1.59596700 \\
\hline & $\mathrm{H}$ & 0.84622700 & -1.20122900 & -1.75150000 \\
\hline & $\mathrm{H}$ & 1.19144800 & -2.28775000 & -0.38384000 \\
\hline & $\mathrm{O}$ & 1.07699200 & 0.58581300 & 1.79140600 \\
\hline & $\mathrm{O}$ & -0.43688900 & 1.95881500 & -0.11565800 \\
\hline & $\mathrm{O}$ & -1.18508700 & -1.42538800 & -0.02802500 \\
\hline & $\mathrm{O}$ & -2.28349500 & -0.59634800 & 0.33848300 \\
\hline & $\mathrm{O}$ & 2.30182600 & -0.63955700 & -0.39403500 \\
\hline & $\mathrm{O}$ & 2.22033700 & 0.70919000 & -0.81142200 \\
\hline \multirow[t]{13}{*}{$\mathrm{TS}_{3-9}$} & $\mathrm{C}$ & 3.36455900 & -0.52590400 & 0.16944900 \\
\hline & $\mathrm{C}$ & -0.66189600 & -0.09675800 & -0.29344300 \\
\hline & $\mathrm{C}$ & -1.06174600 & 1.30679200 & -0.47400200 \\
\hline & $\mathrm{H}$ & 2.98341200 & -1.40154200 & 0.73309100 \\
\hline & $\mathrm{C}$ & 2.58652000 & 0.76061900 & 0.38958100 \\
\hline & $\mathrm{C}$ & -1.56156100 & -1.29836500 & -0.13190300 \\
\hline & $\mathrm{H}$ & -3.34463600 & 0.53747800 & 0.50299400 \\
\hline & $\mathrm{H}$ & -0.21113800 & 1.96536400 & -0.72197600 \\
\hline & $\mathrm{H}$ & 3.08505400 & 1.32681000 & 1.18851200 \\
\hline & $\mathrm{H}$ & 2.59086000 & 1.36568600 & -0.52337700 \\
\hline & $\mathrm{H}$ & -1.39355200 & -1.71789900 & 0.86975200 \\
\hline & $\mathrm{H}$ & -1.26919300 & -2.05271400 & -0.87046800 \\
\hline & $\mathrm{O}$ & -2.18999700 & 1.74016500 & -0.37557700 \\
\hline
\end{tabular}




$\begin{array}{lrrr}\mathrm{O} & 4.32641500 & -0.58780100 & -0.54140000 \\ \mathrm{O} & 0.60301500 & -0.34088400 & -0.28855200 \\ \mathrm{O} & 1.30177900 & 0.52331700 & 0.87919500 \\ \mathrm{O} & -2.91666300 & -1.05628700 & -0.35156300 \\ \mathrm{O} & -3.42905500 & -0.39119600 & 0.78581900\end{array}$




\section{Reference}

(1) Wennberg, P. O.; Bates, K. H.; Crounse, J. D.; Dodson, L. G.; McVay, R. C.; Mertens, L. A.; Nguyen, T. B.; Praske, E.; Schwantes, R. H.; Smarte, M. D.; St Clair, J. M.; Teng, A. P.; Zhang, X.; Seinfeld, J. H. Gas-Phase Reactions of Isoprene and Its Major Oxidation Products. Chem. Rev. 2018, 118, 3337-3390.

(2) Atkinson, R.; Arey, J. Gas-Phase Tropospheric Chemistry of Biogenic Volatile Organic Compounds: A Review. Atmos. Environ. 2003, 37, 197-219.

(3) Ragains, M. L.; FinlaysonPitts, B. J. Kinetics and Mechanism of the Reaction of Cl Atoms with 2-Methyl-1,3-Butadiene (Isoprene) at 298 K. J. Phys. Chem. A 1997, 101, 1509-1517.

(4) Fantechi, G.; Jensen, N. R.; Saastad, O.; Hjorth, J.; Peeters, J. Reactions of Cl Atoms with Selected Vocs: Kinetics, Products and Mechanisms. J. Atmos. Chem. 1998, 31, 247-267.

(5) Bedjanian, Y.; Laverdet, G.; Le Bras, G. Low-Pressure Study of the Reaction of Cl Atoms with Isoprene. J. Phys. Chem. A 1998, 102, 953-959.

(6) Suh, I.; Zhang, R. Y. Kinetic Studies of Isoprene Reactions Initiated by Chlorine Atom. J. Phys. Chem. A 2000, 104, 6590-6596.

(7) Xing, J.-H.; Takahashi, K.; Hurley, M. D.; Wallington, T. J. Kinetics of the Reaction of Chlorine Atoms with Isoprene (2-Methyl 1,3-Butadiene, $\mathrm{CH}_{2}=\mathrm{C}\left(\mathrm{CH}_{3}\right) \mathrm{CH}=\mathrm{CH}_{2}$ ) at $297 \pm 2$ K. Chem. Phys. Lett. 2009, 472, 39-43.

(8) Guo, X. R.; Ma, F. F.; Liu, C.; Niu, J. F.; He, N.; Chen, J. W.; Xie, H. B. Atmospheric Oxidation Mechanism and Kinetics of Isoprene Initiated by Chlorine Radicals: A Computational Study. Sci. Total Environ. 2020, 712, 136330.

(9) Lee, C.; Yang, W.; Parr, R. G. Development of the Colle-Salvetti Correlation-Energy Formula into a Functional of the Electron Density. Phys. Rev. B: Condens. Matter Mater. Phys. 1988, 37, 785-789.

(10) Ahlrichs, R.; Bar, M.; Haser, M.; Horn, H.; Kolmel, C. Electronic-Structure Calculations on Workstation Computers - the Program System Turbomole. Chem. Phys. Lett. 1989, 162, 165-169.

(11) Peeters, J.; Nguyen, T. L.; Vereecken, L. HO ${ }_{x}$ Radical Regeneration in the Oxidation of Isoprene. Phys. Chem. Chem. Phys. 2009, 11, 5935-5939.

(12) Lee, J.; Bozzelli, J. W. Thermochemical and Kinetic Analysis of the Allyl Radical with $\mathrm{O}_{2}$ Reaction System. P. Combust. Inst. 2005, 30, 1015-1022.

(13) Adler, T. B.; Knizia, G.; Werner, H. J. A Simple and Efficient CCSD(T)-F12 Approximation. J. Chem. Phys. 2007, 127, 221106.

(14) Werner, H. J.; Knizia, G.; Manby, F. R. Explicitly Correlated Coupled Cluster Methods with Pair-Specific Geminals. Mol. Phys. 2011, 109, 407-417.

(15) Vereecken, L.; Glowacki, D. R.; Pilling, M. J. Theoretical Chemical Kinetics in Tropospheric Chemistry: Methodologies and Applications. Chem. Rev. 2015, 115, 4063-4114.

(16) Møller, K. H.; Berndt, T.; Kjaergaard, H. G. Atmospheric Autoxidation of Amines. Environ. Sci. Technol. 2020, 54, 11087-11099. 
(17) Ma, F. F.; Xie, H.-B.; Li, M. X.; Wang, S. N.; Zhang, R. Y.; Chen, J. W. Autoxidation Mechanism for Atmospheric Oxidation of Tertiary Amines: Implications for Secondary Organic Aerosol Formation. Chemosphere 2020, 129207.

(18) Peeters, J.; Müller, J.-F.; Stavrakou, T.; Nguyen, V. S. Hydroxyl Radical Recycling in Isoprene Oxidation Driven by Hydrogen Bonding and Hydrogen Tunneling: The Upgraded Lim1 Mechanism. J. Phys. Chem. A 2014, 118, 8625-8643.

(19) Ghosh, B.; Bugarin, A.; Connell, B. T.; North, S. W. Isomer-Selective Study of the $\mathrm{OH}$-Initiated Oxidation of Isoprene in the Presence of $\mathrm{O}_{2}$ and NO: 2. The Major $\mathrm{OH}$ Addition Channel. J. Phys. Chem. A 2010, 114, 2553-2560.

(20) Barker, J. R. Multiple-Well, Multiple-Path Unimolecular Reaction Systems. I. Multiwell Computer Program Suite. Int. J. Chem. Kinet. 2001, 33, 232-245.

(21) Barker, J. R.; Ortiz, N. F. Multiple-Well, Multiple-Path Unimolecular Reaction Systems. II. 2-Methylhexyl Free Radicals. Int. J. Chem. Kinet. 2001, 33, 246-261.

(22) Ortiz, N. F.; Preses, J. M.; Lohr, L. L.; Maranzana, A.; Stimac, P. J.; Nguyen, T. L.; Kumar, T. J. D. University of Michigan: Ann Arbor, Mi, 2014. http://aoss.engin.umich.edu/multiwell/.

(23) Carr, S. A.; Glowacki, D. R.; Liang, C. H.; Baeza-Romero, M. T.; Blitz, M. A.; Pilling, M. J.; Seakins, P. W. Experimental and Modeling Studies of the Pressure and Temperature Dependences of the Kinetics and the $\mathrm{OH}$ Yields in the Acetyl $+\mathrm{O}_{2}$ Reaction. J. Phys. Chem. A 2011, 115, 1069-1085.

(24) Hutter, J.; Iannuzzi, M.; Schiffmann, F.; VandeVondele, J. Cp2k: Atomistic Simulations of Condensed Matter Systems. Wiley Interdiscip. Rev.: Comput. Mol. Sci. 2014, 4, 15-25.

(25) Grimme, S.; Antony, J.; Ehrlich, S.; Krieg, H. A Consistent and Accurate Ab Initio Parametrization of Density Functional Dispersion Correction (DFT-D) for the 94 Elements H-Pu. J. Chem. Phys. 2010, 132, 19.

(26) Lippert, G.; Hutter, J.; Parrinello, M. A Hybrid Gaussian and Plane Wave Density Functional Scheme. Mol. Phys. 1997, 92, 477-487.

(27) Goedecker, S.; Teter, M.; Hutter, J. Separable Dual-Space Gaussian Pseudopotentials. Phys. Rev. B 1996, 54, 1703-1710.

(28) Yu, Q.; Xie, H.-B.; Li, T.; Ma, F. F.; Fu, Z. H.; Wang, Z. Y.; Li, C.; Fu, Z. Q.; Xia, D. M.; Chen, J. W. Atmospheric Chemical Reaction Mechanism and Kinetics of 1,2Bis(2,4,6-Tribromophenoxy)Ethane Initiated by OH Radical: A Computational Study. RSC Adv. 2017, 7, 9484-9494.

(29) Yu, Q.; Xie, H. B.; Chen, J. W. Atmospheric Chemical Reactions of Alternatives of Polybrominated Diphenyl Ethers Initiated by $\cdot \mathrm{OH}$ : A Case Study on Triphenyl Phosphate. Sci. Total Environ. 2016, 571, 1105-1114.

(30) Ma, F. F.; Ding, Z. Z.; Elm, J.; Xie, H. B.; Yu, Q.; Liu, C.; Li, C.; Fu, Z. Q.; Zhang, L. L.; Chen, J. W. Atmospheric Oxidation of Piperazine Initiated By ·Cl: Unexpected High Nitrosamine Yield. Environ. Sci. Technol. 2018, 52 9801-9809.

(31) Tang, B.; Li, Z. Molecular Mechanisms and Atmospheric Implications of Criegee Intermediate-Alcohol Chemistry in the Gas Phase and Aqueous Surface Environments. J. Phys. Chem. A 2020, 124, 8585-8593. 
(32) Møller, K. H.; Otkjær, R. V.; Hyttinen, N.; Kurtén, T.; Kjaergaard, H. G. CostEffective Implementation of Multiconformer Transition State Theory for Peroxy Radical Hydrogen Shift Reactions. J. Phys. Chem. A 2016, 120, 10072-10087.

(33) Møller, K. H.; Otkjær, R. V.; Chen, J.; Kjaergaard, H. G. Double Bonds Are Key to Fast Unimolecular Reactivity in First-Generation Monoterpene Hydroxy Peroxy Radicals. J. Phys. Chem. A 2020, 124, 2885-2896.

(34) Møller, K. H.; Bates, K. H.; Kjaergaard, H. G. The Importance of Peroxy Radical Hydrogen-Shift Reactions in Atmospheric Isoprene Oxidation. J. Phys. Chem. A 2019, 123, 920-932.

(35) Vereecken, L.; Peeters, J. The 1,5-H-Shift in 1-Butoxy: A Case Study in the Rigorous Implementation of Transition State Theory for a Multirotamer System. $J$. Chem. Phys. 2003, 119, 5159-5170. 